\title{
Factors associated with the rapid emergence of zoonotic Bartonella infections
}

\author{
Henri-Jean BoulOuIs ${ }^{\mathrm{a}}$, Chao-chin $\mathrm{CHANG}^{\mathrm{b}}$, Jennifer B. HENN ${ }^{\mathrm{c}}$, \\ Rickie W. KASTEN ${ }^{\mathrm{c}}$, Bruno B. CHOMEL ${ }^{\mathrm{c} *}$ \\ ${ }^{a}$ Microbiologie-Immunologie, École Nationale Vétérinaire d'Alfort, \\ 7 avenue du Général de Gaulle, 94704 Maisons-Alfort, France \\ ${ }^{b}$ Institute of Veterinary Public Health, School of Veterinary Medicine, National Chung Hsing University, \\ 250 Kuo-Kuang Road, Taichung 402, Taiwan, Republic of China \\ ${ }^{c}$ WHO/PAHO Collaborating Center on New and Emerging Zoonoses, Department of Population Health \\ and Reproduction, School of Veterinary Medicine, University of California, Davis, CA 95616, USA
}

(Received 13 October 2004; accepted 17 December 2004)

\begin{abstract}
Within the last 15 years, several bacteria of the genus Bartonella were recognized as zoonotic agents in humans and isolated from various mammalian reservoirs. Based on either isolation of the bacterium or PCR testing, eight Bartonella species or subspecies have been recognized as zoonotic agents, including $B$. henselae, $B$. elizabethae, $B$. grahamii, $B$. vinsonii subsp. arupensis, $B$. vinsonii subsp. berkhoffii, $B$. grahamii, $B$. washoensis and more recently $B$. koehlerae. The present manuscript reviews the factors associated with the emergence of these zoonotic pathogens, including better diagnostic tools and methods to identify these fastidious bacteria, host immunosuppression (caused by infectious agents, cancer, aging or induced by immunosuppressive drugs), the interaction of co-infection by several infectious agents that may enhanced the pathogenecity of these bacteria, increased outdoor activity leading to exposure to wildlife reservoirs or vectors, poverty and low income associated with infestation by various ectoparasites, such as body lice and finally the dispersal of Bartonellae around the world. Furthermore, a description of the main epidemiological and clinical features of zoonotic Bartonellae is given. Finally, the main means for diagnosis, treatment and prevention of these diseases are presented.
\end{abstract}

Bartonella spp. / emerging zoonoses / cat / dog / rodents

Table of contents

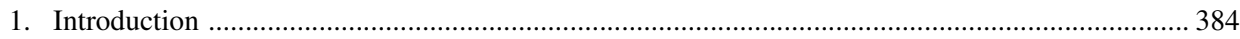

2. Factors of emergence of zoonotic Bartonellae ….............................................................. 385

2.1. Advanced diagnostic tools and methods .................................................................... 385

2.2. Weakening of the host immune system associated with the emergence of immunocompromising diseases, organ transplant and cancer therapy ............................. 385

2.3. Co-infection by several infectious agents ................................................................ 385

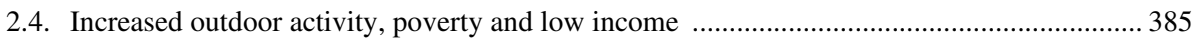

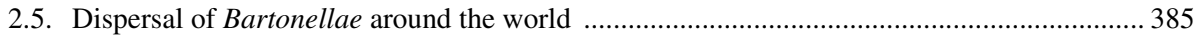

\footnotetext{
* Corresponding author: bbchomel@ucdavis.edu
} 


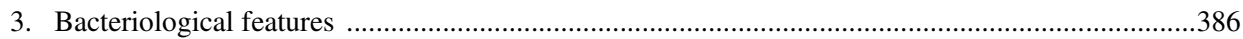

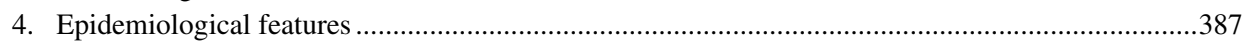

4.1. Zoonotic Bartonellae with a feline or canine reservoir ...........................................................387

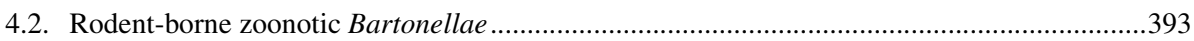

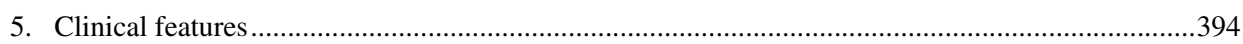

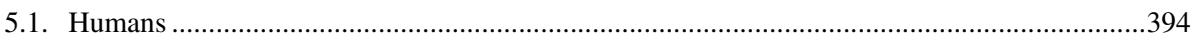

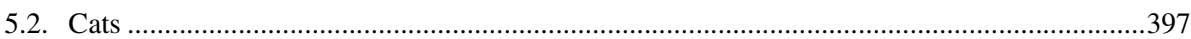

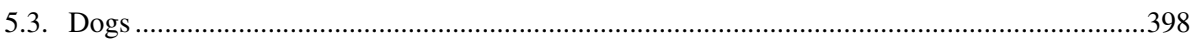

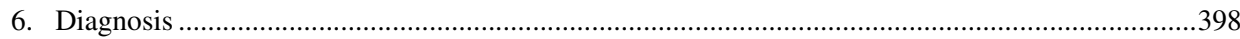

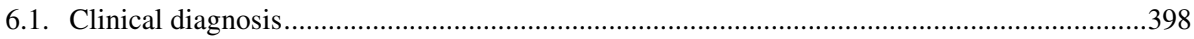

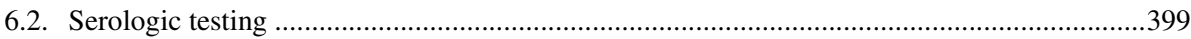

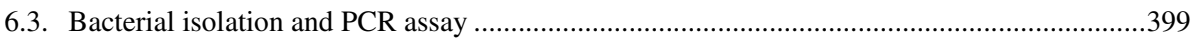

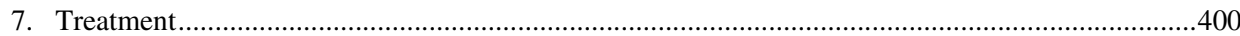

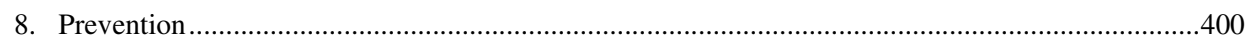

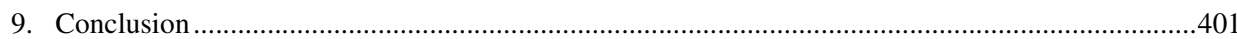

\section{INTRODUCTION}

Within the last 15 years, several new bacteria of the genus Bartonella were recognized as emerging zoonotic agents in humans and isolated from several mammalian reservoirs. If cat scratch disease (CSD) was a well known zoonosis in search of an etiological agent, the recognition of Bartonella henselae as its main etiological agent lead to the recognition of several different clinical syndromes caused by this bacterium in humans and in carnivores. In fact, the recognition of $B$. henselae as the agent of CSD was indirectly the result of the identification of a new bacterium causing a new zoonosis called bacillary angiomatosis in immunocompromised individuals, mainly AIDS patients [191, 193]. Furthermore, several rodent-borne Bartonella emerged as zoonotic agents in both humans and dogs [52].

Bartonella spp. are fastidious hemotropic Gram-negative organisms that have been recently identified in a wide range of domestic and wild mammals [25]. Based on either isolation of the bacterium or PCR testing, eight Bartonella species or subspecies have been recognized as zoonotic agents, including B. henselae, B. elizabethae, B. grahamii,
B. vinsonii subsp. arupensis, B. vinsonii subsp. berkhoffii, B. grahamii, B. washoensis [52] and more recently B. koehlerae [8]. At present, B. clarridgeiae is only considered as a possible zoonotic agent based on serological evidence in infected humans $[136,159,205]$. Bartonella species are usually vector-borne and the vector varies with the Bartonella species involved (i.e. sandflies for B. bacilliformis or human body lice for B. quintana) [52]. Although cat scratch disease (CSD) was described in France more than 50 years ago by Debré et al. [63], it is only in the last decade that Bartonella henselae was recognized as its etiological agent [69, 191, 235]. Cats represent the main reservoir of this bacterium, which is transmitted from cat to cat via the cat flea (Ctenocephalides felis) [46, 128]. Since the isolation of $B$. henselae from domestic cats in 1992, several new Bartonella species or subspecies have been identified in domestic and wild carnivores [52]. Similarly, new species of Bartonella have been identified in wild rodents and domestic and wild ruminants, with an increasing number of reports of human and canine infections caused by some of these rodent-borne Bartonella species. 


\section{FACTORS OF EMERGENCE OF ZOONOTIC BARTONELLAE}

Several factors have lead to the emergence of Bartonellae as agents of zoonotic infections, which include:

\subsection{Advanced diagnostic tools and methods}

Among these, the development of molecular biology tools, especially the use of the polymerase chain reaction (PCR), improved the identification of these fastidious bacteria. Most human cases are now diagnosed based on PCR testing of tissue biopsies or serology using specific antigens, as isolation from the blood is quite uncommon from most cases [115]. Similarly, isolation of Bartonella from dogs is quite rare and most cases have been identified based on PCR of tissue samples, such as cardiac valves and liver biopsies [52].

\subsection{Weakening of the host immune system associated with the emergence of immunocompromising diseases, organ transplant and cancer therapy}

The first isolation of $B$. henselae was performed from the bloodstream of an AIDS patient presenting with very low CD4 counts [191], as severely immunocompromised people can be bacteremic for several weeks when suffering from bacillary angiomatosis [127]. Cases of bacillary angiomatosis were then associated with this bacterium when such patients had been exposed to a domestic cat (usually being scratched) [129]. Recently, a high rate of Bartonella henselae infection in HIV-positive outpatients in Johannesburg, South Africa was reported with almost $10 \%$ of the 188 patients being Bartonella bacteremic, as determined by nested polymerase chain reaction [87].

\subsection{Co-infection by several infectious agents}

Severe clinical forms of $B$. henselae infections have been reported in patients coinfected with other infectious organisms, such as Borrelia [78, 185], HIV [130] or EspteinBarr virus [209]. In dogs, all Bartonella endocarditis cases reported in a study from northern California were seropositive for A. phagocytophilum, suggesting that coinfection by these two vector-borne agents could lead to this severe pathology [154]. Similarly, in the eastern USA and in Thailand, co-infection of dogs with several tickborne pathogens, including Bartonella has been documented [27, 138, 181, 215, 220].

\subsection{Increased outdoor activity, poverty and low income}

Human exposure to some rodent-borne Bartonellae, especially B. elizabethae has been associated with exposure to rats among homeless people or intravenous drug users in urban areas of the USA $[42,56,57,77]$ or to outdoor activity in northern Europe, especially in orienteers in Sweden [155, 229]. Exposure to ticks has also been suggested for human infections [78, 152, 235]. Additionally, it was demonstrated that for dogs, living in a rural environment and being heavily exposed to ticks and fleas were risk factors associated with Bartonella infection [181]. In northern California, herding dogs were more likely to be Bartonella seropositive and toy dogs less likely to be seropositive than other breeds of dogs [107].

\subsection{Dispersal of Bartonellae around the world}

Ellis et al. [77] and Childs et al. [42] have both stated that: "accumulating data suggest an Old World origin for a group of bacteria that include $B$. elizabethae, a human pathogen first identified from the New World. The potential public health significance of these newly described organisms is undefined, but of international interest as their vertebrate reservoir has been introduced 
throughout the world". Similarly, the distribution in various parts of the world of different genotypes/phenotypes of $B$. henselae by human's migrating with their pet cats may have occurred in the last few centuries. A recent report of the presence of $B$. henselae DNA in the teeth of cats buried in France between the XIIIth and XVIth Centuries indicated the presence of mainly genotype Houston I whereas in present times genotype Marseille is highly predominant in cats in that country [142]. It is also interesting to note that some reports $[16,68]$ have emphasized that $B$. henselae genotype Houston was more commonly identified in human cases of CSD whereas genotype Marseille was predominantly isolated within the respective cat populations.

\section{BACTERIOLOGICAL FEATURES}

Bartonellaceae are small gram-negative rods. Until recently, the genus Bartonella consisted of only one species, B. bacilliformis. The genus now combines all the species of the three genera Bartonella, Rochalimaea, and Grahamella into the family Bartonellaceae and the genus Bartonella; the family Bartonellaceae has also been removed from the order Rickettsiales [21, 30]. They are members of the alpha- 2 subgroup of the alpha-proteobacteria. Most of these bacteria are erythrocyte-adherent bacilli. The present family consists of more than 20 species or subspecies, of which at least eight are human pathogens [52].

Bartonellaceae are fastidious, aerobic, short, pleomorphic gram-negative coccobacillary or bacillary rods $(0.6 \mu \mathrm{m} \times 1.0 \mu \mathrm{m})$ that take from 5 to 15 days and up to 45 days on primary culture to form visible colonies on enriched blood-containing media, as they are highly hemin-dependent [44]. In infected tissues, Warthin-Starry silver impregnation stain reveals small bacilli, which tend to appear as clumps of tightly compacted organisms. Similarly, small organisms can be identified in red blood cells by MayGrünwald Giemsa coloration. Bartonellae have a close evolutionary homology with members of the genera Brucella, Agrobacterium and Rhizobium. Bartonellaceae have the ability to infect red blood cells and to cause prolonged intraerythrocytic bacteremia in their specific mammalian reservoir host [64]. Such an infection has been well described in an experimental model of infection of rats with B. tribocorum [207]. Furthermore, these bacteria are unique among all known bacterial pathogens in their ability to cause vasoproliferative lesions through their ability to invade endothelial cells and trigger proliferation and migration of these cells [64].

Traditionally, Bartonella are cultivated in semisolid nutrient agar containing fresh rabbit blood (or sheep or horse blood) at $35{ }^{\circ} \mathrm{C}$ (except for B. bacilliformis, which grows best at $28^{\circ} \mathrm{C}$ ) in $5 \% \mathrm{CO}_{2}$. On primary isolation, some Bartonella, such as B. henselae, B. clarridgeiae, B. vinsonii, or B. elizabethae have colonies with a white, rough, dry, raised appearance and pit the medium. They are hard to break up or transfer. Because of the slow growth of these bacteria, standard biochemical methods for identification may not be applicable. The Bartonella are catalase, oxidase, urease and nitrate reductase negative [25]. Measurement of preformed enzymes and standard testing has revealed differences between Bartonella species. Most species are biochemically inert except for the production of peptidases [25].

Molecular genetic methods such as restriction fragment length polymorphism (RFLP) of genes encoding citrate synthase, 16S rRNA or 16S-23S rRNA spacer region, and more recently analysis based on polymerase chain reaction (PCR) of random, repetitive extragenic palindromic sequences have been used to distinguish strains and species of Bartonella. RFLP or sequence analysis of $16 \mathrm{~S}$ rRNA, citrate synthase genes after PCR amplification both directly from specimens or pure cultures have been largely used for detecting and characterizing Bartonella. More recently, identification has also been performed with the amplification of the $16 \mathrm{~S}-23 \mathrm{~S}$ rRNA intergenic 
spacer region (ITS) [201] or protein-coding genes. The genes the more widely used are those coding for the citrate synthase ( gltA), the heat shock protein ( $g r o E L)$, the riboflavine $(r i b C)$, the RNA polymerase beta subunit $(r p o B)$, a cell division protein ( fts $Z$ ) and a $17 \mathrm{kDa}$ antigen [145].

\section{EPIDEMIOLOGICAL FEATURES}

\subsection{Zoonotic Bartonellae with a feline or canine reservoir}

Cat scratch disease is certainly the most common Bartonella zoonosis worldwide. Human cases have been reported from several continents, including North America, Europe, Australia, and from most countries where investigators looked for such an infection [25, 52]. It has been estimated that more than 22000 human cases occurred in the USA in 1992, with an estimated incidence of disease in ambulatory patients of 9.3 per 100000 persons per year [113]. In the Netherlands, the estimated number of CSD was 2000 cases per year or 12.5 cases/ 100000 persons [17]. Therefore, such observations suggest that worldwide several thousand cases of CSD may occur every year in many countries. Overall, CSD is more likely to occur in children and young adults [35]. Transmission from cat to human mainly occurs directly by a cat scratch and possibly via a cat bite [35] or possibly by a flea or a tick bite [152, 197, 235]. However, it is now suggested that flea bites are an unlikely mode of infection and that flea feces may be the only infecting material that could be inoculated by a cat scratch $[83,84]$. B. henselae DNA was recently detected in a biting fly, raising concern about the role of these biting insects as Bartonella vector [54]. In immunocompromised individuals, bacillary angiomatosis and bacillary peliosis caused by $B$. henselae are usually associated with exposure to cats and cat fleas [127, 129]. However, bacillary peliosis was a clinical feature seen only in patients infected with B. henselae [129]. Different Bartonella species, but more frequently $B$. henselae and
B. quintana, can cause human endocarditis [31]. An estimated 3\% of all cases of human endocarditis have been attributed to Bartonella infection [189]. However, only $B$. henselae is considered to be zoonotic among these two Bartonella species. In Sweden, the emergence of orienteering (countryside running based on navigational acuity using map and compass-reading skills) was marked between 1979 and 1992 by an elevated rate of sudden unexpected cardiac deaths in top-ranked competitors [229]. Four of these deaths were likely caused by $B$. henselae and B. quintana, as DNA was detected in the cardiac tissue of 4 of the 5 cases tested and in the lung of the fifth case, whereas no Bartonella DNA was detected in six control hearts.

In humans, $B$. clarridgeiae antibodies have been reported in a suspect case of CSD and in a patient with a chest-wall abscess [136, 159]. Furthermore, anti-flagella (FlaA) specific antibodies against $B$. clarridgeiae were detected in $3.9 \%$ of 724 patients with lymphadenopathy [205]. However, significant cross-reactivity between $B$. henselae and $B$. clarridgeiae was noted in a recent study from Japan [219]. These serological investigations suggest that $B$. clarridgeiae may be a minor causative agent of CSD.

More recently, the first human case of endocarditis associated with B. koehlerae, was reported from Israel [8]. Furthermore, these authors were able to isolate $B$. koehlerae from a bacteremic stray cat from that country.

Domestic cats are the main reservoir for $B$. henselae, B. clarridgeiae and B. koehlerae [45, 128, 192]. Sero-epidemiological and bacteriological studies have demonstrated the worldwide distribution of $B$. henselae infection in domestic cats. $B$. henselae antibody prevalence varies from $5 \%$ to $80 \%$, and bacteremia prevalence ranges from a few percent to more than half of the population tested, according to the geographical location and the cat status (pet or stray). Data of surveys concerning cat populations are summarized in Tables I, II, III for 
Table I. Surveys of Bartonella spp. infections (bacteremia or antibodies) in domestic cats in France, Germany and the Netherlands.

\begin{tabular}{|c|c|c|c|c|c|}
\hline Country (location) & Survey & Cat population & Bartonella & $\begin{array}{c}\text { Prevalence } \\
\text { positive/total }(\%)\end{array}$ & Reference \\
\hline \multirow[t]{7}{*}{ France (Paris) } & B & Pets & B.spp. & 72/436 (16.5) & [100] \\
\hline & & & B.h. & $\mathrm{H}: 11 / 72(\mathbf{1 5 . 3})$ & \\
\hline & & & & M: 36/72 (50) & \\
\hline & & & & $\mathrm{H}+\mathrm{M}: 2 / 72(\mathbf{2 . 8})$ & \\
\hline & & & B.c. & $15 / 72(\mathbf{2 0 . 8})$ & \\
\hline & & & B.h. + B.c. & $8 / 72(2)$ & \\
\hline & S & Pets & B.h. + B.c. & 179/436 (41.1) & \\
\hline \multirow[t]{4}{*}{ France (Lyon) } & B & Pets & B.spp. & 8/99 (8.1) & [199] \\
\hline & & & B.h. & $\mathrm{H}: 6 / 8$ (75) & \\
\hline & & & & M: 0/8 (0) & \\
\hline & & & B.c. & 2/8 (25) & \\
\hline \multirow[t]{4}{*}{ France (Nancy) } & B & Strays & B.spp. & $50 / 94(\mathbf{5 3})$ & [106] \\
\hline & & & B.h. & H: $17 / 50$ (34) & \\
\hline & & & & M: 18/50 (36) & \\
\hline & & & B.c. & $15 / 50(\mathbf{3 0})$ & \\
\hline \multirow[t]{4}{*}{ France (Marseille?) } & B & Strays & B.spp. & $38 / 61(\mathbf{6 2 . 3})$ & [143] \\
\hline & & & B.h. & H: 15/38 (39.5) & \\
\hline & & & & M: 7/38 (18.4) & \\
\hline & & & B.c. & 16/38 (42.1) & \\
\hline Germany & S & Pets & B.h. & 107/713 (15) & [103] \\
\hline Germany (Freiburg) & B & Pets & B.h. & 13/100 (13) & [203] \\
\hline \multirow[t]{6}{*}{ Germany (Berlin) } & B & Pets/Strays & B.h. & 20/193 (10.4) & [7] \\
\hline & & & & Pets: 1/97 (1) & \\
\hline & & & & Stray: 19/96 (18.7) & \\
\hline & & & & H: $1 / 20(\mathbf{5})$ & \\
\hline & & & & M: 18/20 (90) & \\
\hline & & & B.c. & $1 / 20$ (a stray cat) $(\mathbf{5})$ & \\
\hline \multirow[t]{8}{*}{ The Netherlands } & B & Shelter & B.h. & 25/113 (22) & [17] \\
\hline & & & & H: 6/25 (24) & \\
\hline & & & & M: 10/25 (40) & \\
\hline & & & B.h./B.c. & $5 / 25(\mathbf{2 0})$ & \\
\hline & & & B.c. & $4 / 25(\mathbf{1 6})$ & \\
\hline & $S$ & Shelter/Pets & B.h. & Not given (35-60) & \\
\hline & & & & Pets: $28 / 50(\mathbf{5 6})$ & \\
\hline & & & & Shelter: 56/113 (50) & \\
\hline
\end{tabular}

S: seroprevalence, B: bacteremia prevalence, B.h.: Bartonella henselae, B.c.: Bartonella clarridgeiae, B.spp.: Bartonella species, H: type I (Houston I), M: type II (Marseille). 
Table II. Surveys of Bartonella spp. infections (bacteremia or antibodies) in domestic cats in northern and central Europe.

\begin{tabular}{|c|c|c|c|c|c|}
\hline Country & Survey & Cat population & Bartonella & $\begin{array}{c}\text { Prevalence } \\
\text { positive/total }(\boldsymbol{\%})\end{array}$ & Reference \\
\hline Austria & $S$ & Pets & B.h. & $32 / 96(\mathbf{3 3 . 3})$ & [3] \\
\hline \multirow[t]{5}{*}{ Czech Republic } & B & Pets/Shelter/ & B.h. & $5 / 61(8)$ & {$[170]$} \\
\hline & & Stray & & M: 5/5 (100) & \\
\hline & & & & Pets: 0/34 (0) & \\
\hline & & & & Shelter: 1/21 (5) & \\
\hline & & & & Stray: 4/6 (66.6) & \\
\hline \multirow[t]{6}{*}{ Denmark } & B & Pets/Shelter & B.h. & 21/93 (22.6) & [49] \\
\hline & & & & $\mathrm{H}: 1 / 21$ (5) & \\
\hline & & & & M: 20/21 (95) & \\
\hline & & & & Pets: 8/44 (18.2) & \\
\hline & & & & Shelter: $13 / 49$ (26.5) & \\
\hline & $S$ & Pets/Shelter & B.h. & 42/92 (45.6) & \\
\hline Denmark & B & Strays & B.h. & $11 / 25(\mathbf{4 4})$ & [75] \\
\hline (North Zealand) & & & & M: 11/11 (100) & \\
\hline \multirow[t]{3}{*}{ Norway } & B & Pets & B.spp. & 0/100 (0) & [15] \\
\hline & S & Pets & B.h. (EIA) & $1 / 100(\mathbf{1})$ & \\
\hline & & & B.h. (IFA) & 0/100 (0) & \\
\hline Poland & $S$ & Shelters & B.h. & $31 / 36(\mathbf{8 6})$ & [184] \\
\hline Sweden & S & Pets & B.h. & 3/292(1) & [108] \\
\hline Sweden & B & Pets & B.h. & 2/91 (2.2) & {$[76]$} \\
\hline $\begin{array}{l}\text { (Stockholm and } \\
\text { southern Sweden) }\end{array}$ & & & & M: $2 / 2(\mathbf{1 0 0})$ & \\
\hline Switzerland & S & Pets & B.h. & $60 / 728(8.3)$ & [92] \\
\hline United Kingdom & B & Pets & B.h. & $34 / 360(\mathbf{9 . 4})$ & [22] \\
\hline (Bristol and & & & & $\mathrm{H}: 2 / 34(\mathbf{6})$ & \\
\hline \multirow[t]{2}{*}{ Southwest UK) } & & & & M: 30/34 (88) & \\
\hline & & & & $H+M: 2 / 34(6)$ & \\
\hline \multirow[t]{2}{*}{ United Kingdom } & $S$ & Pets & B.h. & 28/69 (40.6) & [13] \\
\hline & S & Feral & B.h. & $33 / 79$ (41.8) & \\
\hline United Kingdom & B & Pets & B.h. & 40/351 (11.4) & [147] \\
\hline
\end{tabular}

S: seroprevalence, B: bacteremia prevalence, B.h.: Bartonella henselae, B.c.: Bartonella clarridgeiae, B.spp.: Bartonella species, EIA: ELISA, IFA: immunofluorescence, H: type I (Houston I), M: type II (Marseille). 
Table III. Surveys of Bartonella spp. infections (bacteremia or antibodies) in domestic cats in Italy and Portugal.

\begin{tabular}{|c|c|c|c|c|c|}
\hline Country & Survey & Cat population & Bartonella & $\begin{array}{c}\text { Prevalence } \\
\text { positive/total }(\%)\end{array}$ & Reference \\
\hline \multirow{5}{*}{$\begin{array}{l}\text { Italy (Lombardia) } \\
\text { (3 urban, } 3 \text { rural areas) }\end{array}$} & B & Stray & B.spp. & $140 / 769(\mathbf{1 8})$ & [81] \\
\hline & & & B.h. & H: 27/131 (20.6) & \\
\hline & & & & M: 80/131 (61.1) & \\
\hline & & & & $H+M: 24 / 131(\mathbf{1 8})$ & \\
\hline & S & Stray & B.h. & $207 / 540(\mathbf{3 8})$ & \\
\hline \multirow[t]{5}{*}{ Italy (northern) } & B & Stray & B.h. & $361 / 1585(\mathbf{2 3})$ & [82] \\
\hline & & & & Not given (26) & \\
\hline & & & & Not given (52) & \\
\hline & & & B.c. & Not given (5) & \\
\hline & $S$ & Stray & B.h. & $553 / 1416(39)$ & \\
\hline \multirow[t]{2}{*}{ Italy (Tuscany) } & B & Pets/catteries & B.spp. & 0/28 (0) & [73] \\
\hline & S & Pets/catteries & B.h. & 98/427 (23) & \\
\hline $\begin{array}{l}\text { Italy } \\
\text { (Reggio Emilia) }\end{array}$ & B & Pets & B.h. & $24 / 248(9.7)$ & [33] \\
\hline Portugal & $\mathrm{S}$ & Pets & B.h. & $1 / 14(6.7)$ & [41] \\
\hline
\end{tabular}

S: seroprevalence, B: bacteremia prevalence, B.h.: Bartonella henselae, B.c.: Bartonella clarridgeiae, B.spp.: Bartonella species, H: type I (Houston I), M: type II (Marseille).

Europe, Table IV for Asia and Oceania, Table V for the Americas and Table VI for Africa and the Middle East. Cats are usually bacteremic for several weeks, based on experimental infections; but some cats can be bacteremic for more than a year, as shown in natural settings $[132,133]$ or experimentally $[1,131,135,137]$. However, prevalence and level (number of colony forming units per millilitre of blood) of bacteremia are usually higher in young cats $(<1$ year) than in adult cats [45]. Two main genotypes/serotypes of $B$. henselae have been described [16, 70, 144], and major regional variations in the respective prevalence of $B$. henselae type I (Houston) and type II (Marseille) have been reported in domestic cat populations (Tabs. I-VI). Co-infection of cats with these two genotypes has also been reported [17, 99]. Transmission of infection among cats requires the presence of fleas [46]. However, it is strongly suggested that infection among cats is occurring through inoculation of flea feces rather than flea bites [83, 84]. Bartonella clarridgeiae is unevenly distributed in cat populations worldwide, with a prevalence of $30 \%$ to $36 \%$ of all Bartonella isolates in some studies (France, the Netherlands or Philippines) to no more than $10 \%$ in the southeastern USA and Japan or Taiwan and lack of isolation in several studies in Europe, Australia and North America [52, 95]. Bartonella koehlerae has been isolated only from two cats in California, one cat in France and recently in one cat in Israel $[8,72,196]$. Furthermore, Bartonella infection has been reported in wild felids, such as pumas and bobcats in the New World [53].

Bartonella vinsonii subsp. berkhoffii was identified in a human case of endocarditis 
Table IV. Surveys on Bartonella spp. infections (bacteremia or antibodies) in domestic cats in Asia and Oceania.

\begin{tabular}{|c|c|c|c|c|c|}
\hline Country & Survey & Cat Population & Bartonella & $\begin{array}{c}\text { Prevalence } \\
\text { positive/total (\%) }\end{array}$ & Reference \\
\hline $\begin{array}{l}\text { Australia } \\
\text { (Sydney) }\end{array}$ & B & Pets/Feral & B.h. & $\begin{array}{c}\text { 27/77 (35) } \\
\text { Pets: } 3 / 18(\mathbf{1 6}) \\
\text { Feral: } 24 / 59(\mathbf{4 0})\end{array}$ & [24] \\
\hline $\begin{array}{l}\text { Australia } \\
\text { (Melbourne) }\end{array}$ & B & Pets & B.h. & 45/342 (13.2) & [174] \\
\hline $\begin{array}{l}\text { New Zealand } \\
\text { (Auckland) }\end{array}$ & B & Pets & B.h. & $8 / 48$ (17) & [117] \\
\hline Japan & S & Pets & B.h. & 30/199 (15.1) & [221] \\
\hline Japan & $S$ & Pets & B.h. & 43/471 (9.1) & [165] \\
\hline (Kanagawa, $\mathrm{S}$ & Prefectu & & & & \\
\hline Japan & S & Pets & B.h. & $128 / 1447(\mathbf{8 . 8})$ & [168] \\
\hline Japan & B & Pets/Pound & B.h. & 3/33 (9.1) & [164] \\
\hline Japan & B & Pets & $\begin{array}{l}\text { B.spp. } \\
\text { B.h. }\end{array}$ & $\begin{array}{c}\text { 50/690 (7.2) } \\
\text { H: 43/45 (95.5) } \\
\text { M: } 1 / 45 \text { (2.2) }\end{array}$ & [166] \\
\hline & & & $\begin{array}{c}\text { B.c. } \\
\text { B.c. + B.h. }\end{array}$ & $\begin{array}{l}4 / 50(\mathbf{8}) \\
1 / 50(\mathbf{2})\end{array}$ & \\
\hline $\begin{array}{c}\text { Indonesia } \\
\text { (Jakarta) }\end{array}$ & B & Stray & $\begin{array}{l}\text { B.h. } \\
\text { B.c. }\end{array}$ & $\begin{array}{l}6 / 14(\mathbf{4 3}) \\
3 / 14(\mathbf{2 1})\end{array}$ & [163] \\
\hline & S & Stray & B.h. & 40/74 (54) & \\
\hline $\begin{array}{l}\text { Philippines } \\
\text { (Manilla) }\end{array}$ & B & Stray & $\begin{array}{c}\text { B.spp. } \\
\text { B.h. } \\
\text { B.c. } \\
\text { B.h. + B.c. } \\
\text { B.h. } \\
\text { B.c. }\end{array}$ & $\begin{array}{c}\text { 19/31 (61) } \\
\text { H: } 13 / 19(\mathbf{6 8 . 4}) \\
2 / 19(\mathbf{1 0 . 5}) \\
4 / 19(\mathbf{2 1}) \\
73 / 107(\mathbf{6 8}) \\
70 / 107(\mathbf{6 5})\end{array}$ & [47] \\
\hline Singapore & $S$ & Stray & B.h. & $38 / 80$ (47.5) & {$[173]$} \\
\hline Thailand & B & Pets/Stray & $\begin{array}{c}\text { B.spp. } \\
\text { B.h. } \\
\text { B.c. } \\
\text { B.h. + B.c. } \\
\text { B.h. }\end{array}$ & $\begin{array}{c}\text { 76/275 (27.6) } \\
\text { 63/76 (83) } \\
\text { 9/76 (11.8) } \\
4 / 76 \text { (5.3) } \\
\text { H: 48/67 (71.6) } \\
\text { M: } 13 / 67(\mathbf{1 9 . 4})\end{array}$ & [167] \\
\hline
\end{tabular}

S: seroprevalence, B: Bacteremia prevalence, B.h.: Bartonella henselae, B.c.: Bartonella clarridgeiae, B.spp.: Bartonella species, H: type I (Houston I), M: type II (Marseille). 
Table V. Surveys on Bartonella spp. infections (bacteremia or antibodies) in domestic cats in the Americas.

\begin{tabular}{|c|c|c|c|c|c|}
\hline Country & Survey & Cat population & Bartonella & $\begin{array}{c}\text { Prevalence } \\
\text { positive/total (\%) }\end{array}$ & Reference \\
\hline Brazil & $S$ & Pets? & B.h. & Not given (46) & cited in [224] \\
\hline Chile (Valdivia) & S & Pets & $\begin{array}{l}\text { B.h. } \\
\text { B.c. }\end{array}$ & $\begin{array}{c}54 / 76(\mathbf{7 1}) \\
\text { Not given (18.6) }\end{array}$ & [236] \\
\hline Canada & $\mathrm{S}$ & Pets & B.h. & $43 / 242(\mathbf{1 7 . 8})$ & [149] \\
\hline USA/Canada & $\mathrm{S}$ & Pets & B.h. & $175 / 628(\mathbf{2 7 . 9})$ & [116] \\
\hline USA & S & Pets/Shelter & B.h. & $370 / 1314$ (28.2) & [41] \\
\hline USA (Baltimore) & $S$ & Stray/Vet. Hosp. & B.h. & 77/592 (13) & [40] \\
\hline $\begin{array}{l}\text { USA } \\
\text { (North Carolina) }\end{array}$ & $S$ & Pets & B.h. & $46 / 114(\mathbf{4 0 . 4})$ & [12] \\
\hline $\begin{array}{l}\text { USA } \\
\text { (Florida) }\end{array}$ & $S$ & Feral/Stray & B.h. & $186 / 553($ 33.6) & [153] \\
\hline $\begin{array}{l}\text { USA } \\
\text { (North Carolina) }\end{array}$ & $\begin{array}{l}S \\
S\end{array}$ & $\begin{array}{l}\text { Feral } \\
\text { Pets }\end{array}$ & $\begin{array}{l}\text { B.h. } \\
\text { B.h }\end{array}$ & $\begin{array}{c}93 / 100(\mathbf{9 3}) \\
57 / 76(\mathbf{7 5})\end{array}$ & [176] \\
\hline \multicolumn{6}{|l|}{ USA } \\
\hline \multirow{2}{*}{ (California) } & & & & $\begin{array}{l}\text { Pets: 24/112 (21.4) } \\
\text { Stray: 57/93 (61.3) }\end{array}$ & \\
\hline & $S$ & Pets/Stray & B.h. & $165 / 205(\mathbf{8 1})$ & \\
\hline \multirow[t]{6}{*}{ USA } & B & Pets & B.h. & 65/271 (24) & [98] \\
\hline & & & & H: $14 / 49$ (28.6) & \\
\hline & & & & M: 32/49 (65.3) & \\
\hline & & & & $\mathrm{H}+\mathrm{M}: 3 / 49(\mathbf{6 . 1})$ & \\
\hline & & & B.c. & (0) & \\
\hline & $\mathrm{S}$ & Pets & B.h. & 138/271 (51) & \\
\hline
\end{tabular}

S: seroprevalence, B: Bacteremia prevalence, B.h.: Bartonella henselae, B.c.: Bartonella clarridgeiae, B.spp.: Bartonella species, H: type I (Houston I), M: type II (Marseille). 
Table VI. Serosurveys on Bartonella spp. infection in domestic cats in Africa and the Middle East.

\begin{tabular}{lccccc}
\hline Country & Survey & Cat population & Bartonella & $\begin{array}{c}\text { Prevalence } \\
\text { positive/total (\%) }\end{array}$ & Reference \\
\hline Egypt & S & Pets & B.h. & $5 / 42(\mathbf{1 2})$ & {$[41]$} \\
Israel & S & Pets & B.h. & $45 / 114(\mathbf{3 9 . 5})$ & {$[12]$} \\
Israel & B & Stray & B.h. & $40 / 48(\mathbf{8 3})$ & {$[8]$} \\
& & & B.c. & $7 / 48(\mathbf{1 5})$ & $1 / 48(\mathbf{2})$ \\
Jordan & S & Pets & B.h. & $55 / 153(\mathbf{3 6})$ & {$[4]$} \\
& & & & true prevalence (32) & \\
South Africa & S & Shelter & B.h. & $11 / 52(\mathbf{2 1})$ & {$[120]$} \\
& B & Pets & B.h. & $1 / 31(\mathbf{3 . 2})(\mathrm{H}: 1 / 1)$ & {$[187]$} \\
& & & B.h. & $28 / 119(\mathbf{2 4})$ & {$[120]$} \\
Zimbabwe & S & Pets/Shelter & B.h. & $2 / 25(\mathbf{8})$ & {$[121]$} \\
\hline
\end{tabular}

S: seroprevalence, B: Bacteremia prevalence, B.h.: Bartonella henselae, B.c.: Bartonella clarridgeiae, B.k.: Bartonella koehlerae, B.spp.: Bartonella species, H: type I (Houston I), M: type II (Marseille).

[200]. This subspecies appears to be the most common Bartonella species/subspecies causing endocarditis in dogs [25]; however, other Bartonella species, including B. clarridgeiae, B. washoensis have been identified in canine endocarditis cases $[48$, $50,154]$. Overall, the prevalence of $B$. vinsonii subsp. berkhoffii antibodies in pet dogs is quite low $(<5 \%)$ [107, 181, 212], but can be higher in specific populations $[11,111]$ and in free-roaming dogs in the tropics ranging from 19\% (5/26) for dogs from French Guyana and Martinique to $65 \%$ (33/51) for native dogs from Sudan ${ }^{1}$. In the western USA, coyotes (Canis latrans) constitute a major reservoir for Bartonella vinsonii subsp. berkhoffii [37, 38]. Limited data is available about the seroprevalence of $B$. henselae in dogs $[13,65,107]$ which was found to also be quite low. However, a recent study reported higher prevalence of $B$. henselae antibodies in healthy $(10.1 \%)$ and sick $(27.2 \%)$ dogs from the southeastern USA [212].

\subsection{Rodent-borne zoonotic Bartonellae}

At present, only a limited number of human infections caused by rodent-borne Bartonella species or subspecies have been described in the scientific literature. There are still many unknown risk factors associated with such infections (i.e. mode of

\footnotetext{
${ }^{1}$ Davoust B., Drancourt M., Boni M., et al., Survey of seroprevalence of Bartonella vinsonii, Ehrlichia canis and Coxiella burnetii in dogs in southeast France, French Guyana, Martinique, Senegal, Ivory Coast and Sudan, EUWOG-ASR Joint Meeting, Marseille, France, 14-16 June 1999, Abstract 232B.
} 
infection, vector involved, source of infection). Among the rodent-borne Bartonellae, B. elizabethae infection seems to be quite prevalent in intravenous (IV) drug users and homeless people in various parts of the USA and also in Sweden [56, 57, 156], based on serological studies. In IV drug users, B. elizabethae seroprevalence ranged from 33\% in Baltimore [56] to 39\% in Stockholm [156] and 46\% in New York [57]. In homeless people from Los Angeles, California, the seroprevalence was $12.5 \%$ [210]. Furthermore, $31 \%$ of 1136 Swedish orienteers were seropositive for B. elizabethae [155]. Infections caused by $B$. elizabethae in humans have been associated with endocarditis and neuroretinitis [60, 177]. However, such studies based only on serological data need to be confirmed by identification of this pathogen either by PCR methods or isolation. Rats (Rattus norvegicus) constitute the main reservoir of B. elizabethae [42,77]. This Bartonella species has been isolated from urban rats from various parts of the world, including the USA (Louisiana, Maryland), Portugal and Peru [19,77]. In China, Yunnan rats are infected with a large number of Bartonella strains that are genetically related to $B$. elizabethae [234]. In Thailand, a number of the Bartonella isolates from Thai rodents are closely related to $B$. grahamii and B. elizabethae, two species that have been associated with human illness [36].

Bartonella grahamii has been mainly isolated from bank voles (Clethrionomys glareolus) in the United Kingdom [20] and Poland [10] and from yellow-necked mice (Apodemus flavicollis) in Sweden [110], but has also been isolated from rats in the USA and a domestic mouse captured in California [77]. The rodent flea Ctenophthalmus nobilis was recently shown to be a competent vector of at least two Bartonella species, B. grahamii, which has previously been associated with human ocular infection (neuroretinitis and retinal artery occlusion) [123, 208], and B. taylorii [23]. Whitefooted mice (Peromyscus leucopus) are the reservoir of $B$. vinsonii subspecies arupen- sis, which has been isolated from $5 \%$ of 81 mice tested from Minnesota and Wisconsin and associated with one human infection (fever, bacteremia, neurological symptoms) [109, 228]. California ground squirrels (Spermophilus beecheyi) are the main reservoir of $B$. washoensis, which has been identified in a human case of myocarditis [139] and in a case of endocarditis in a dog [50]. Finally, isolation of $B$. henselae type Houston I from three long-tailed field mice (Apodemus sylvaticus) was very recently reported [75] and raises an interesting question about the possibility of natural infection of wild rodents with $B$. henselae. Further studies will be required to determine if rodents could be another natural reservoir of this bacterium beside its feline reservoir.

The epidemiological importance of rodentborne Bartonella spp. as a cause of disease in animals and man is emerging, as suggested for a novel rodent Bartonella-associated febrile illness in the rural southwestern USA, based on serological evidence ${ }^{2}$. A few patients had high antibody titers against a strain of Bartonella isolated from a whitethroaded wood rat (Neotoma albigula). Many new Bartonella species have been identified in South East Asia [36, 234] and some of them could be a source of human infection (Kosoy M., personal communication).

\section{CLINICAL FEATURES}

\subsection{Humans}

Classical Cat Scratch Disease: CSD caused by $B$. henselae is mainly characterized by a benign regional lympadenopathy $[35,43,63,157]$. Usually after a cat scratch, a papule and then a pustule develops within

\footnotetext{
${ }^{2}$ Kosoy M., Ying B., Koster F., Gage K., Ecological and epidemiological implications of high genetic and antigenic diversity of rodentborne Bartonella strains in the US West, American Society for Rickettsiology - Bartonella as an emerging pathogen group. 2001 joint conference, Big Sky, Montana, USA, 18-22 August 2001, Abstract 108.
} 
Table VII. Miscellanous manifestations of Bartonella henselae infection in humans.

\begin{tabular}{lc}
\hline Clinical manifestations & References \\
\hline Tumoral and Pseudotumoral manifestations of CSD & {$[93,160]$} \\
Mimicking breast tumor, breast mass & {$[150]$} \\
Granulomatous hepatitis and necrotizing splenitis & {$[90,183,231]$} \\
Simulating lymphoma & {$[140]$} \\
Gammopathy & {$[161]$} \\
Simulating rhabdomyosarcoma & {$[122]$} \\
Mimicking parotid malignancy & {$[74]$} \\
Pseudotumoral presentation & {$[172]$} \\
Simulating a malignant process of the chest wall & {$[14]$} \\
Peripheral lymphadenopathy & {$[225]$} \\
Myelodysplastic syndrome & \\
Joint and/or bone localisation & {$[5,105]$} \\
Arthritis, arthralgy & {$[148]$} \\
Osteomyelitis & \\
Skin localisation & {$[206]$} \\
Skin nodules, cutaneous vasculitis & {$[211]$} \\
Erythema nodosum, granuloma annulare & {$[225]$} \\
Petechial, papular and vasculitic skin lesions, & {$[146]$} \\
Unusual eruption & {$[202]$} \\
Paronychia & {$[31,70,85,101,189,223]$} \\
Miscellaneous & {$[9]$} \\
Endocarditis & {$[206]$} \\
Henoch-Schonlein purpura & {$[223]$} \\
Gurpura with leukocytoclasic vasculitis & {$[55]$} \\
Periodontitis & \\
\hline &
\end{tabular}

7 to 12 days at the inoculation site $[35,115$, 157]. A regional lymphadenopathy (usually involving a single lymph node) develops one to three weeks after the inoculation and can persist a few weeks to several months [35]. Abscessed lymph nodes are reported occasionally in $12 \%$ [35] up to $48 \%$ of the cases [62]. Low-grade fever, malaise and aching are often reported; and in some instances, headache, anorexia and splenomegaly can occur. The various clinical manifestations of $B$. henselae infection are summarized in Table VII.
Atypical CSD: From 5\% to 9\% of CSD cases may develop atypical manifestations, including Parinaud's oculoglandular syndrome, encephalitis, endocarditis, hemolytic anemia, hepatosplenomegaly, glomerulonephritis, pneumonia, relapsing bacteremia, and osteomyelitis [157]. Cat scratch disease encephalopathy (CSDE), possibly associated with an immune-mediated response to $B$. henselae infection, is one of the most severe complications of CSD [175]. Patients with CSDE usually completely recover within one year without any sequelae. However, 
Table VIII. Neurologic manifestations of Bartonella henselae infection in humans.

\begin{tabular}{lc}
\hline Clinical signs & References \\
\hline Epilepsia partialis continua & {$[188]$} \\
Encephalopathy & {$[102,162,175]$} \\
Status epilepticus & {$[6,79,102]$} \\
Peripheral facial nerve paralysis & {$[227]$} \\
Coma & {$[102]$} \\
Fatal meningitis and & {$[89,162]$} \\
encephalitis & \\
Meningoencephalitis & {$[216]$} \\
Meningitis & {$[230]$} \\
Hemiplegia & {$[195]$} \\
\hline
\end{tabular}

one case of fatal meningitis and encephalitis was reported in a 4-year-old child [89].

An expanding clinical spectrum associated with $B$. henselae infection: $B$. henselae has been identified as a frequent cause of prolonged fever and fever of unknown origin in children [114, 217, 218].

Besides a wider spectrum of neurological symptoms (Tab. VIII), many ocular lesions have also been associated with Bartonella infection, such as uveitis, focal retinal phlebitis, neuroretinitis, retinal and opti- cal nerve neovascularization, retinal artery and vein occlusion (Tab. IX). It is important to indicate that most of these observations have mainly been based on the presence of Bartonella antibodies or a proven seroconversion rather than by isolation or positive PCR.

Tumoral and pseudo-tumoral lesions have also been reported, such as lesions mimicking breast tumor or rhabdomyosarcoma, lymphoma and gammopathy, as well as granulomatous hepatitis and necrotizing splenitis (Tab. VII). Rheumatic manifestations (arthralgia, arthritis) of Bartonella infection have been described both in children and adults (Tab. VII), as well as erythema nodosum $[35,211]$, leukocytoclastic vasculitis [104], fever of unknown origin with myalgia [114] and arthralgia [5, 35, 105]. Cases of osteomyelitis have also been described [148]. A causative role for $B$. henselae in Henoch-Schonlein purpura (HSP) was suggested based on serological evidence, as $12(67 \%)$ of 18 HSP patients were seropositive versus only 8 (14\%) of 57 controls [9]. HSP is an immune-mediated vasculitis that is characterized by excessive IgA production and frequently associated with thrombocytopenia. Monoclonal and biclonal

Table IX. Ocular manifestations of Bartonella spp. infection in humans.

\begin{tabular}{lc}
\hline Clinical signs & References \\
\hline Uveitis & {$[71,179]$} \\
Multifocal retinitis, neuroretinitis/stellate neuroretinitis (Leber's & {$[18,58,59,126,169,179,180]$} \\
neuroretinitis) macular star/neovascularization & \\
Parinaud's oculoglandular syndrome & {$[58,80]$} \\
Retinal artery and vein occlusion, neovascular glaucoma, & {$[94]$} \\
severe vision loss. & {$[226]$} \\
Optic disk edema with peripapillary serous retinal detachment & {$[94]$} \\
Peripapillary angioma, & {$[67]$} \\
Retinochoroidal exsudate, retinal phlebitis & {$[88]$} \\
Disciform keratitis & {$[169]$} \\
Retinal and optic nerve neovascularization & {$[58,186]$} \\
Focal retinochoroiditis, unifocal helioid choroiditis & {$[125]$} \\
Posterior segment involvement & \\
\hline
\end{tabular}


gammopathy in two patients infected with Bartonella henselae has also been described [140]. Bartonella have also been suggested as a cause of granulum annulare [211] and glomerulonephritis associated with negative culture endocarditis [223]. The first case of spontaneous splenic rupture caused by infection with $B$. henselae was recently reported, leading to massive hemoperitoneum [61]. Lesion of the spleen is common in disseminated infection with $B$. henselae [213], but massive spontaneous hemoperitoneum was only reported in association with hepatic bacillary peliosis in an HIVinfected patient [151].

Bartonella spp. were first described as a cause of human endocarditis in three separate reports in 1993, one caused by B. quintana in an immunocompromised individual [214], one caused by B. elizabethae in an immunocompetent patient [60] and the third caused by $B$. (Rochalimaea) henselae [101]. Bartonella species, mainly B. quintana and $B$. henselae, account for approximately $3 \%$ of human endocarditis cases, with more than 100 human cases reported in the international literature since 1993 $[85,189,190]$. In most human cases of Bartonella endocarditis, the vegetative lesions are preferentially located on the aortic valve [189] and most patients have high antibody titers [86]. Furthermore, most cases of $B$. henselae endocarditis are culture negative but positive by DNA amplification [85]. Bartonella henselae and B. quintana DNA were also detected in the cardiac tissue of four young Swedish orienteers who died of unexpected sudden cardiac death [229].

In immunocompromised individuals, bacillary angiomatosis (BA) is one of the most common clinical manifestations of Bartonella infections [127]. The presence of chronic vascular proliferative lesions is observed. HIV infected patients with CD4 ${ }^{+}$cell counts of less than $50 / \mathrm{mm}^{3}$ are more likely to develop BA lesions. Histopathologically, cutaneous BA is characterized by a tumorlike growth pattern with proliferation of capillaries having protuberant epitheloid endothelial cells [127, 193]. In transplant patients, various clinical manifestations or pathological lesions have been reported, such as pulmonary nodules [34] or sternal abscess [32], disseminated infection with granulomatous hepatitis [112], acute organ rejection [66], bacillary peliosis [2] and bacillary angiomatosis [118]. A case of hemophagocytic syndrome in a transplant patient was recently associated with $B$. henselae infection [119]. Hemophagocytic syndrome (HPS) combines febrile hepatosplenomegaly, pancytopenia, hypofibrinemia, and liver dysfunction.

\subsection{Cats}

Cats usually appear to be healthy carriers of $B$. henselae, as limited pathology has been associated with natural infection. However, due to the high prevalence of infection in cat populations, it has been difficult to attribute specific clinical signs to cats naturally infected with $B$. henselae [43, 45]. Based on serological results, naturally infected cats were more likely to have lymphadenitis and gingivitis, especially those co-infected with the feline immunodeficiency virus [222]. Such an association was also demonstrated between $B$. henselae seropositivity and presence of stomatitis or urological diseases [92]. Bartonella henselae has been implicated as a potential cause of anterior uveitis in cats [141] and a PCR confirmed case of $B$. henselae endocarditis was described in a cat from California [51].

In experimental conditions, cats infected with $B$. henselae (mainly type II, feline isolates) have developed various clinical signs $[96,137,178]$. The most commonly reported sign is fever, which usually does not last for more than a week [95]. Local inflammation (erythema, swelling) at the site of inoculation and localized or generalized lymphadenopathy have also been observed. Some other signs include lethargy and anorexia. Some cats also developed mild neurological signs, such as nystagmus, tremors, focal motor seizures, and behavior changes [95]. Reproductive disorders (stillbirths, lack of 
pregnancy or pregnancy only after repeated breedings) were reported in experimentally infected queens [97]. Variation in pathogenicity of strains has been suggested for differences in clinical signs observed in experimental conditions [178].

\subsection{Dogs}

The first isolation of Bartonella from a dog occurred in a case of endocarditis in 1993 [26, 134]. Since then, Bartonella vinsonii subsp. berkhoffii has been identified as an important cause of canine endocarditis $[26,28]$, and was determined as the cause of one human endocarditis case [200]. As in humans, the clinical spectrum of Bartonella infection in dogs is expanding, as it is now associated with cardiac arrhythmias, endocarditis and myocarditis [28], as well as granulomatous lymphadenitis and granulomatous rhinitis [182]. In both humans and dogs, Bartonella associated cases of endocarditis usually involve the aortic valve and are characterized by massive vegetative lesions [154]. At one veterinary teaching hospital, Bartonella infection was implicated in almost one third of the endocarditis cases diagnosed over a two-year period [154]. Based upon serological evidence, infection with $B$. vinsonii subsp. berkhoffii may also cause immune-mediated hemolytic anemia, neutrophilic or granulomatous meningo encephalitis, neutrophilic polyarthritis, cutaneous vasculitis, and uveitis in dogs [29]. A case-control study of clinical diagnosis associated with dogs seropositive for Bartonella spp. suggests an association with lameness, arthritis-related lameness, splenomegaly and nasal discharge/epistaxis [107]. However, B. vinsonii subsp. berkhoffii has also been isolated from clinically healthy dogs, which may be long-term carriers of the bacterium [132]. Dogs can be infected by several other zoonotic Bartonella species, including $B$. clarridgeiae isolated from the blood of a dog with endocarditis [48] and detected by PCR in a dog with hepatic lymphocytic hepatitis [91]. $B$. henselae DNA has been detected in a dog with peliosis hepatis [124] and more recently in a dog with granulomatous hepatopathy [91]. Bartonella henselae DNA was amplified from the blood of three dogs with various clinical entities [171]. Bartonella elizabethae DNA was also detected in the blood of a sick dog [171]. Finally, B. washoensis, a rodent borne zoonotic Bartonella, was isolated from a dog suffering from mitral endocarditis [50].

\section{DIAGNOSIS}

\subsection{Clinical diagnosis}

In humans, clinical diagnosis of cat scratch disease is based on detection of an enlarged lymph node and possibly the presence of a small vesicle or granuloma at the inoculation site. However, clinical diagnosis of atypical forms of CSD and other emerging syndromes associated with $B$. henselae infection or other zoonotic Bartonella species is not easy and requires laboratory diagnostic means. In culture negative cases, using classical isolation media, the presence of epidemiological factors such a cat scratch or bite, owning a cat, possible contact with rodent, with fleas, ticks or other blood sucking arthropods may suggest such an etiology and should lead to Bartonella specific testing (serology, culture or PCR).

In dogs and cats, clinical diagnosis is usually not easy, as the clinical spectrum of Bartonella infection is not fully elucidated. Bartonella infection should be suspected in dogs with endocarditis, especially if affecting the aortic valve [154]. It also should be suspected in dogs with prolonged or intermittent fever, lethargy, unexplained lameness, or unexplained granulomatous disease. Similarly, veterinarians should consider performing a diagnostic test for Bartonella infection in sick dogs, when there is clinical or epidemiological suspicion of tick exposure. Thrombocytopenia, anemia, neutrophilic leukocytosis, and eosinophilia are the most commonly detected hematologic abnormalities in dogs seropositive for B. vinsonii 
subsp. berkhoffii [29]. In all cases, suspicion of Bartonella infection is mainly established through serological testing, which provides evidence of Bartonella exposure $[113,115]$.

\subsection{Serologic testing}

In humans, serologic testing (mainly IFA testing) is the reference test for diagnosis of cat scratch disease [86, 115]. An IgG anti$B$. henselae antibody titer $\geq 1: 64$ is considered as positive for infection when patients are tested at least two to three weeks after a suspected infection. Bartonella-associated endocarditis in humans and animals is usually associated with much higher IFA antibody titers $(>1: 800)[86,115]$. Commercially prepared IFA slides for $B$. henselae and $B$. quintana antigens are available. Zangwill et al. [235] estimated the sensitivity and specificity of a $B$. henselae-based IFA to be $84 \%$ and $96 \%$, respectively. A study comparing two commercially available IFA tests reported that the tests for IgG antibodies to $B$. henselae had higher sensitivities (100\% and $85 \%$, respectively) than specificities (70\% and $73 \%$, respectively), although this may have been the result of previous exposure to $B$. henselae among the healthy controls designated as the noninfected group [204]. Furthermore, a limiting diagnostic factor in humans is the lack of commercial tests for most rodent-borne zoonotic Bartonella species.

In cats, serologic testing is of limited diagnostic value, as many cats (especially stray cats) are likely to be seropositive against $B$. henselae [45]. Testing is indicated in kittens or recently adopted cats, because seronegative cats are more likely not to be bacteremic. Similarly, persons who may have immunocompromising conditions should require that an IFA test detecting antibodies against $B$. henselae be performed on cats prior to adoption. However, bacteremia in seronegative cats has been reported in a few instances and the antibodies usually cross-react with several Bartonella antigens [52]. As shown in one of our studies, serological screening for Bartonella antibodies may not be useful for the identification of bacteremic cats (positive predicite value $=46.4 \%$ ), but the lack of antibodies to $B$. henselae was highly predictive of the absence of bacteremia (negative predicite value $=89.7 \%$ ) [45]. Because of these limitations for serologic testing, bacterial isolation or PCR assay are necessary to identify the infecting Bartonella spp.

In dogs, as for humans, diagnosis of Bartonella infection is largely based on the presence of specific antibodies. Testing for various antigens seems to be appropriate, including $B$. vinsonii berkhoffii and $B$. henselae [107, 212].

No formal test evaluation studies have been undertaken to estimate the sensitivities and specificities of the serological tests commonly used for the diagnosis of Bartonella infection in cats and dogs. One study investigating the seroprevalence of $B$. henselae and $B$. quintana among pet cats in Jordan did provide estimates of sensitivity and specificity for the IFA used in the study [4]. That author reported that the sensitivities of the $B$. henselae $\operatorname{IgG}$ and B. quintana IgG IFA tests were $99 \%$ and $88 \%$, respectively, while the specificities were $94 \%$ and $90 \%$, respectively. These results will have to be validated, however, as it is unclear how infection status of cats was determined and whether they were representative of a population of naturally infected cats.

\subsection{Bacterial isolation or PCR assay}

Isolation of Bartonella spp. from cats or from humans with bacillary angiomatosis (for whom serologic testing may not be useful, because patients often do not mount detectable antibodies) is much easier than isolation of those organisms from other animal species or non-immunocompromised individuals. A positive blood culture or culture of other tissue is the most reliable test for definitive diagnosis of active Bartonella infection [95]. However, in cats, multiple blood cultures may be necessary because of 
the relapsing nature of feline Bartonella bacteremia [137]. In humans with cat scratch disease or dogs with Bartonella infection, isolation of these bacteria is rarely successful. Isolation of Bartonella from blood samples is performed usually by using either pediatric lysis-centrifugation tubes or more commonly plastic tubes containing EDTA. The use of plastic EDTA tubes has the advantage to prevent breakage of the blood tube when subjected to low temperature freezing and avoid the risk of sample contamination during transfer from glass to plastic tubes prior to freezing. Anticoagulated blood is plated (usually after freezing to induce RBC lysis) onto fresh rabbit blood agar and incubated for at least four weeks at $35{ }^{\circ} \mathrm{C}$ with an atmosphere containing $5 \%$ carbon dioxide. Identification of the isolate is performed using molecular techniques, such as PCR or partial sequencing of selected genes.

Compared with bacteriologic culture, extraction of DNA from tissue samples and PCR testing has been more successful as a method of diagnosis of Bartonella infection in humans and dogs $[115,127,154,191]$. Frozen tissue samples or fresh biopsy specimens can be easily tested. Polymerase chain reaction assay of paraffin-embedded tissues is more cumbersome, but possible. Testing should be performed by laboratory personnals who are familiar with processing these fastidious organisms; laboratories should be contacted for specific instructions for sample collection and submission.

\section{TREATMENT}

In humans, infected with $B$. henselae, treatment is different for immunocompetent patients having classical symptoms of cat scratch disease than for immunocompromised patients with angiomatous proliferative diseases [127]. For immunocompetent patients, numerous antimicrobial agents have been advocated for the treatment of typical CSD. However, in most instances, antibiotics do not appear to shorten or improve the course of the infection [198].
In human cases of Bartonella endocarditis, effective antibiotic therapy should include an aminoglycoside prescribed for a minimum of two weeks [190]. In immunocompromised patients with bacillary angiomatosis or bacillary peliosis, the effectiveness of treatments with various antimicrobial substances has been evaluated [127]. Overall, tetracyclines, erythromycin, rifampin, azithromycin, doxycycline or a combination of these antibiotics are effective and should be administered in these patients for at least six weeks and be continued for 4 to 6 months in those who have relapses [158, 198].

In cats, antimicrobial agents are not commonly used or recommended for treatment or prevention of $B$. henselae, as antibiotic treatments tested to date may reduce the level of bacteremia but do not clear the cats from their infection [135, 194]. Additionally, the minimal effectiveness of these antimicrobial agents could be explained by the fact that Bartonella species are intracellular organisms.

In dogs, no study has been performed to determine the efficacy of antibiotics for treatment of Bartonella infection. However, it is likely that antibiotics such as doxycycline $(10 \mathrm{mg} / \mathrm{kg} / \mathrm{day})$ or tetracycline could reduce the level of bacteremia during chronic infections, but should be administered for prolonged periods of time (4-6 weeks). Fluoroquinolones alone or in combination with amoxicillin have also elicited a positive therapeutic response in dogs [29], as repeated $B$. vinsonii subsp. berkhoffii antibody titers became negative after treatment. However, antibiotic therapy may not be very effective when the lesions of endocarditis are already well established.

\section{PREVENTION}

Domestic cats represent the main reservoir for $B$. henselae and cat ownership is now surpassing dog ownership in many industrialized countries [52]. Selecting an appropriate pet cat is important to avoid such a 
risk. In most instances, seronegative cats are more likely not to be bacteremic and to be safe for ownership [52]. Conversely, young kittens, especially impounded kittens and flea-infested kittens, are more likely to be bacteremic [45, 128]. It has also been shown that multiple cat ownership was associated with an increased risk for Bartonella infection [100]. Therefore, potential pet cat owners, especially if they are immunocompromised, should seek a cat raised in a "clean", flea-controlled environment. In case of adoption, especially when the cat origin is not well defined, it is recommended that serological testing be performed. Only seronegative cats should be adopted when immunocompromised individuals may be exposed to the adopted cat. Flea control is also one of the major control measures to prevent cat infection and its spread from cat to cat and potentially the spread from cats to humans [43]. Overall, effective means of preventing $B$. henselae infection are common sense, hygiene, and, possibly, modification of behavior of the cat owners themselves. Wash hands after handling pets, and clean any cuts, bites or scratches promptly with soap and water. Development of a feline vaccine to prevent the spread of infection in cat populations and reduce human risk of infection is being considered. However, the wide diversity of Bartonella isolates even within the same genotype has been of concern for development of an effective feline vaccine. The lack of cross-protectivity between $B$. henselae genotype Marseille and $B$. henselae genotype Houston I was demonstrated a few years ago [232]. Nevertheless, a more recent study was able to demonstrate an unidirectional protective effect using a $B$. henselae Houston I strain against a $B$. henselae Marseille strain challenge [233].

Canine Bartonella infections are also likely to be vector-borne and ticks have been suggested as possible vectors of $B$. vinsonii subsp. berkhoffii [27, 39, 181]. Therefore, prevention of tick infestation should be one of the main control measures that are employed in the clinical setting. Use of tick repellents and cleaning of the dog after a walk in high-risk terrain should be done systematically to prevent not only Bartonella, but also other tick-borne infections. Flea control measures are also important, as dogs may become infected with $B$. henselae [212], possibly when exposed to cat fleas, which are known to transmit the infection among cats.

\section{CONCLUSION}

Beside cat scratch disease, a well-known zoonosis for which the etiological agent was finally identified at the end of the XXth Century, several new zoonotic Bartonella infections have recently been recognized. Most of these zoonotic pathogens have a rodent reservoir and it is likely that new rodent-borne Bartonella species will be identified in the near future, some of which will likely be zoonotic. Most Bartonella species are vector borne and such vectors still need to be identified for several emerging zoonotic Bartonella species. Finally, the clinical spectrum of Bartonella infections in both humans and dogs has greatly widened since better tools for identification of these bacteria became available.

\section{REFERENCES}

[1] Abbott R.C., Chomel B.B., Kasten R.W., Floyd-Hawkins K.A., Kikuchi Y., Koehler J.E., Pedersen N.C., Experimental and natural infection with Bartonella henselae in domestic cats, Comp. Immunol. Microbiol. Infect. Dis. 20 (1997) 41-51.

[2] Ahsan N., Holman M.J., Riley T.R., Abendroth C.S., Langhoff E.G., Yang H.C., Peliosis hepatis due to Bartonella henselae in transplantation: a hemato-hepato-renal syndrome,Transplantation 65 (1998) 1000-1003.

[3] Allerberger F., Schonbauer M., Zangerle R., Dierich M., Prevalence of antibody to Rochalimaea henselae among Austrian cats, Eur. J. Pediatr. 154 (1995) 165.

[4] Al-Majali A.M., Seroprevalence of and risk factors for Bartonella henselae and Bartonella quintana infections among pet cats in Jordan, Prev. Vet. Med. 64 (2004) 63-71. 
[5] Al-Matar M.J., Petty R.E., Cabral D.A., Tucker L.B., Peyvandi B., Prendiville J., Forbes J., Cairns R., Rothstein R., Rheumatic manifestations of Bartonella infection in two children, $\mathrm{J}$. Rheumatol. 29 (2002) 184-186.

[6] Armengol C.E., Hendley J.O., Cat-scratch disease encephalopathy: a cause of status epilepticus in school-aged children, J. Pediatr. 134 (1999) 635-638.

[7] Arvand M., Klose A.J., Schwartz-Porsche D., Hahn H., Wendt C., Genetic variability and prevalence of Bartonella henselae in cats in Berlin, Germany, and analysis of its genetic relatedness to a strain from Berlin that is pathogenic for humans, J. Clin. Microbiol. 39 (2001) 743-746.

[8] Avidor B., Graidy M., Efrat G., Leibowitz C., Shapira G., Schattner A., Zimhony O., Giladi M., Bartonella koehlerae, a new cat-associated agent of culture-negative human endocarditis, J. Clin. Microbiol. 42 (2004) 3462-3468.

[9] Ayoub E.M., McBride J., Schmiederer M., Anderson B., Role of Bartonella henselae in the etiology of Henoch-Schonlein purpura, Pediatr. Infect. Dis. J. 21 (2002) 28-31.

[10] Bajer A., Pawelczyk A., Behnke J.M., Gilbert F.S., Sinski E., Factors affecting the component community structure of haemoparasites in bank voles (Clethrionomys glareolus) from the Mazury Lake District region of Poland, Parasitology 122 (2001) 43-54.

[11] Baneth G., Breitschwerdt E.B., Hegarty B.C., Pappalardo B., Ryan J., A survey of tick-borne bacteria and protozoa in naturally exposed dogs from Israel, Vet. Parasitol. 74 (1998) 133-142.

[12] Baneth G., Kordick D.L., Hegarty B.C., Breitschwerdt E.B., Comparative seroreactivity to Bartonella henselae and Bartonella quintana among cats from Israel and North Carolina, Vet. Microbiol. 50 (1996) 95-103.

[13] Barnes A., Bell S.C., Isherwood D.R., Bennett M., Carter S.D., Evidence of Bartonella henselae infection in cats and dogs in the United Kingdom, Vet. Rec. 147 (2000) 673-677.

[14] Benesch M., Kerbl R., Wirnsberger A., Stunzner D., Mangge H., Schenkeli R., Deutsch J., Peripheral lymphadenopathy in childhood - recommendations for diagnostic evaluation, Klin. Pädiatr. 212 (2000) 277-282.

[15] Bergh K., Bevanger L., Hanssen I., Loseth K., Low prevalence of Bartonella henselae infections in Norwegian domestic and feral cats, APMIS 110 (2002) 309-314.

[16] Bergmans A.M., Schellekens J.F., van Embden J.D., Schouls L.M., Predominance of two Bartonella henselae variants among cat-scratch disease patients in the Netherlands, J. Clin. Microbiol. 34 (1996) 254-260.

[17] Bergmans A.M., de Jong C.M., van Amerongen G., Schot C.S., Schouls L.M., Prevalence of Bartonella species in domestic cats in The Netherlands, J. Clin. Microbiol. 35 (1997) 2256-2261.

[18] Bhatti M.T., Asif R., Bhatti L.B., Macular star in neuroretinitis, Arch. Neurol. 58 (2001) 1008-1009.
[19] Birtles R.J., Raoult D., Comparison of partial citrate synthase gene (gltA) sequences for phylogenetic analysis of Bartonella species, Int. J. Syst. Bacteriol. 46 (1996) 891-897.

[20] Birtles R.J., Harrison T.G., Molyneux D.H., Grahamella in small woodland mammals in the UK: isolation, prevalence and host specificity, Ann. Trop. Med. Parasitol. 88 (1994) 317-327.

[21] Birtles R.J., Harrison T.G., Saunders N.A., Molyneux D.H., Proposals to unify the genera Grahamella and Bartonella, with descriptions of Bartonella talpae comb. nov., Bartonella peromysci comb. nov., and three new species, Bartonella grahamii sp. nov., Bartonella taylorii sp. nov., and Bartonella doshiae sp. nov., Int. J. Syst. Bacteriol. 45 (1995) 1-8.

[22] Birtles R.J., Laycock G., Kenny M.J., Shaw S.E., Day M.J., Prevalence of Bartonella species causing bacteraemia in domesticated and companion animals in the United Kingdom, Vet. Rec. 151 (2002) 225-229.

[23] Bown K.J., Bennet M., Begon M., Flea-borne Bartonella grahamii and Bartonella taylorii in bank voles, Emerg. Infect. Dis. 10 (2004) 684687.

[24] Branley J., Wolfson C., Waters P., Gottlieb T., Bradbury R., Prevalence of Bartonella henselae bacteremia, the causative agent of cat scratch disease, in an Australian cat population, Pathology 28 (1996) 262-265.

[25] Breitschwerdt E.B., Kordick D.L., Bartonella infection in animals: Carriership, reservoir potential, pathogenicity, and zoonotic potential for human infection, Clin. Microbiol. Rev. 13 (2000) 428-438.

[26] Breitschwerdt E.B., Kordick D.L., Malarkey D.E., Keene B., Hadfield T.L., Wilson K., Endocarditis in a dog due to infection with a novel Bartonella subspecies, J. Clin. Microbiol. 33 (1995) 154-160.

[27] Breitschwerdt E.B., Hegarty B.C., Hancock S.I., Sequential evaluation of dogs naturally infected with Ehrlichia canis, Ehrlichia chaffeensis, Ehrlichia equi, Ehrlichia ewingii, or Bartonella vinsonii, J. Clin. Microbiol. 36 (1998) 2645-2651.

[28] Breitschwerdt E.B., Atkins C.E., Brown T.T., Kordick D.L., Snyder P.S., Bartonella vinsonii subsp. berkhoffii and related members of the alpha subdivision of the Proteobacteria in dogs with cardiac arrhythmias, endocarditis or myocarditis, J. Clin. Microbiol. 37 (1999) 36183626.

[29] Breitschwerdt E.B., Blann K.R., Stebbins M.E., Munana K.R., Davidson M.G., Jackson H.A., Willard M.D., Clinicopathological abnormalities and treatment response in 24 dogs seroreactive to Bartonella vinsonii (berkhoffii) antigens, J. Am. Anim. Hosp. Assoc. 40 (2004) 92-101.

[30] Brenner D.J., O’Connor S.P., Winkler H.H., Steigerwalt A.G., Proposals to unify the genera Bartonella and Rochalimaea, with descriptions of Bartonella quintana comb. nov., Bartonella vinsonii comb. nov., Bartonella henselae comb. nov., and Bartonella elizabethae comb. nov., and 
to remove the family Bartonellaceae from the order Rickettsiales, Int. J. Syst. Bacteriol. 43 (1993) 777-786.

[31] Brouqui P., Raoult D., Endocarditis due to rare and fastidious bacteria, Clin. Microbiol. Rev. 14 (2001) 177-207.

[32] Bruckert F., de Kerviler E., Zagdanski A.M., Molina J.M., Casin I., Guermazi A., Bedrossian J., Frija J., Sternal abscess due to Bartonella (Rochalimaea) henselae in a renal transplant patient, Skeletal Radiol. 26 (1997) 431-433.

[33] Cabassi C.S., Farnetti E., Casali B., Taddei S., Donofrio G., Galvani G., Cavirani S., Isolation of Bartonella henselae from domestic cats in an Italian urban area, New Microbiol. 25 (2002) 253-257.

[34] Caniza M.A., Granger D.L., Wilson K.H., Washington M.K., Kordick D.L., Frush D.P., Blitchington R.B., Bartonella henselae: etiology of pulmonary nodules in a patient with depressed cell-mediated immunity, Clin. Infect. Dis. 20 (1995) 1505-1511.

[35] Carithers H.A., Cat-scratch disease. An overview based on a study of 1200 patients, Am. J. Dis. Child. 139 (1985) 1124-1133.

[36] Castle K.T., Kosoy M., Lerdthusnee K., Phelan L., Bai Y., Gage K.L., Leepitakrat W., Monkanna T., Khlaimanee N., Chandranoi K., Jones J.W., Coleman R.E., Prevalence and diversity of Bartonella in rodents of northern Thailand: a comparison with Bartonella in rodents from southern China, Am. J. Trop. Med. Hyg. 70 (2004) 429-433.

[37] Chang C.C., Yamamoto K., Chomel B.B., et al., Sero-epidemiology of Bartonella vinsonii subsp. berkhoffii infection in California coyotes, 1994 1998, Emerg. Infect. Dis. 5 (1999) 711-715.

[38] Chang C.C., Kasten R.W., Chomel B.B., Simpson D.C., Hew C.M., Kordick D.L., Heller R., Piemont Y., Breitschwerdt E.B., Coyotes (Canis latrans) as the reservoir for a human pathogenic Bartonella sp.: Molecular epidemiology of Bartonella vinsonii subsp. berkhoffii infection in coyotes from central coastal California, J. Clin. Microbiol. 38 (2000) 4193-4200.

[39] Chang C.C., Chomel B.B., Kasten R.W., Romano V., Tietze N., Molecular evidence of Bartonella spp. in questing adult Ixodes pacificus ticks in California, J. Clin. Microbiol. 39 (2001) 1221-1226.

[40] Childs J.E., Rooney J.A., Cooper J.L., Olson J.G., Regnery R.L., Epidemiologic observations on infection with Rochalimaea species among cats living in Baltimore, Md, J. Am. Vet. Med. Assoc. 204 (1994) 1775-1778.

[41] Childs J.E., Olson J.G., Wolf A., Cohen N., Fakile Y., Rooney J.A., Bacellar F., Regnery R.L., Prevalence of antibodies to Rochalimaea species (catscratch disease agent) in cats, Vet. Rec. 136 (1995) 519-520.

[42] Childs J.E., Ellis B.A., Nicholson W.L., Kosoy M., Sumner J.W., Shared vector-borne zoonoses of the Old World and New World: home grown or translocated? Schweiz. Med. Wochenschr. 129 (1999) 1099-1105.

[43] Chomel B.B., Cat Scratch Disease, Rev. Sci. Tech. Off. Int. Epizoot. 19 (2000) 136-150.

[44] Chomel B.B., Kasten R.W., Bartonellaceae, in Hirsh D.C., MacLachlan N.J., Walker R.L. (Eds.) Veterinary Microbiology, second Edition, Blackwell Publishing, Ames, IA, USA, 2004, pp. 260 264.

[45] Chomel B.B., Abbott R.C., Kasten R.W., FloydHawkins K.A., Kass P.H., Glaser C.A., Pedersen N.C., Koehler J.E., Bartonella henselae prevalence in domestic cats in California: Risk factors and association between bacteremia and antibody titers, J. Clin. Microbiol. 33 (1995) 2445 2450 .

[46] Chomel B.B., Kasten R.W., Floyd-Hawkins K.A., Chi B., Yamamoto K., Roberts-Wilson J., Gurfield A.N., Abbott R.C., Pedersen N.C., Koehler J.E., Experimental transmission of Bartonella henselae by the cat flea, J. Clin. Microbiol. 34 (1996) 1952-1956.

[47] Chomel B.B., Carlos E.T., Kasten R.W., Yamamoto K., Chang C.C., Carlos R.S., Abenes M.V., Pajares C.M., Bartonella henselae and Bartonella clarridgeiae infection in domestic cats from The Philippines, Am. J. Trop. Med Hyg. 60 (1999) 593-597.

[48] Chomel B.B., MacDonald K.A., Kasten R.W., Chang C.C., Wey A.C., Foley J.E., Thomals W.P., Kittleson M.D., Aortic valve endocarditis in a dog due to Bartonella clarridgeiae, J. Clin. Microbiol. 39 (2001) 3548-3554.

[49] Chomel B.B., Boulouis H.J., Petersen H., Kasten R.W., Yamamoto K., Chang C.C., Gandoin C., Bouillin C., Hew C.M., Prevalence of Bartonella infection in domestic cats in Denmark, Vet. Res. 33 (2002) 205-213.

[50] Chomel B.B., Wey A.C., Kasten R.W., Isolation of Bartonella washoensis from a dog with mitral valve endocarditis, J. Clin. Microbiol. 41 (2003) 5327-5332.

[51] Chomel B.B., Wey A.C., Kasten R.W., Stacy B.A., Labelle P., A fatal case of endocarditis in a domestic cat associated with Bartonella henselae type I infection, J. Clin. Microbiol. 41 (2003) 5337-5339.

[52] Chomel B.B., Boulouis H.J., Breitschwerdt E.B., Cat scratch disease and other zoonotic Bartonella infections, J. Am. Vet. Med. Assoc. 224 (2004) 1270-1279.

[53] Chomel B.B., Kikuchi Y., Martenson J.S., RoelkeParker M.E., Chang C.C., Kasten R.W., Foley J.E., Laudre J., Murphy K., Swift P.K., Kramer V.L., O'Brien S.J., Seroprevalence of Bartonella infection in American free-ranging and captive pumas (Felis concolor) and bobcats (Lynx rufus), Vet Res. 35 (2004) 233-241.

[54] Chung C.Y., Kasten R.W., Paff S.M., Van Horn B.A., Vayssier-Taussat M., Boulouis H.J., Chomel B.B., Bartonella spp. DNA associated with biting flies from California, Emerg. Infect. Dis. 10 (2004) 1311-1313. 
[55] Colombo A.P., Teles R.P., Torres M.C., Souto R., Rosalem W.J., Mendes M.C., Uzeda M., Subgingival microbiota of Brazilian subjects with untreated chronic periodontitis, J. Periodontol. 73 (2002) 360-369.

[56] Comer J.A., Flynn C., Regnery R.L., Vlahov D. Childs J.E., Antibodies to Bartonella species in inner-city intravenous drug users in Baltimore, MD, Arch. Intern. Med. 156 (1996) 2491-2495.

[57] Comer J.A., Diaz T., Vlahov D., Monterroso E., Childs J.E., Evidence of rodent-associated Bartonella and Rickettsia infections among intravenous drug users from Central and East Harlem, New York City, Am. J. Trop. Med. Hyg. 65 (2001) 855-860.

[58] Cunningham E.T., Koehler J.E., Ocular bartonellosis, Am. J. Ophthalmol. 130 (2000) 340-349.

[59] Cunningham E.T. Jr., Schatz H., McDonald H.R., Johnson R.N., Acute multifocal retinitis, Am. J. Ophthalmol. 123 (1997) 347-357.

[60] Daly J.S., Worthington M.G., Brenner D.J., Moss C.W., Hollis D.G., Weyant R.S., Steigerwalt A.G., Weaver R.E., Daneshvar M.I., O'Connor S.P., Rochalimaea elizabethae sp. nov. isolated from a patient with endocarditis, J. Clin. Microbiol. 31 (1993) 872-881.

[61] Daybell D., Paddock C.D., Zaki S.R., Comer J.A., Woodruff D., Hansen K.J., Peacock J.E. Jr., Disseminated infection with Bartonella henselae as a cause of spontaneous splenic rupture, Clin. Infect. Dis. 39 (2004) 21-24.

[62] Debré R., Job J.C., La maladie des griffes de chat, Acta Paediatr. Scand. Suppl. 43 (1954) 1-86.

[63] Debré R., Lamy M., Jammet M.L., Costil L., Mozziconacci P., La maladie des griffes de chat, Bull. Memb. Soc. Méd. Hosp. Paris 66 (1950) 76-79.

[64] Dehio C., Molecular and cellular basis of Bartonella pathogenesis, Annu. Rev. Microbiol. 58 (2004) 365-390.

[65] Demers D.M., Bass J.W., Vincent J.M., Person D.A., Noyes D.K., Staege C.M., Samlaska C.P., Lockwood N.H., Regnery R.L., Anderson B.E., Cat-scratch disease in Hawaii: etiology and seroepidemiology, J. Pediatr. 127 (1995) 23-26.

[66] Dharnidharka V.R., Richard G.A., Neiberger R.E., Fennell R.S. 3rd, Cat scratch disease and acute rejection after pediatric renal transplantation, Pediatr. Transplant. 6 (2002) 327-331.

[67] Diaz-Valle D., Toledano Fernandez N., Arteaga Sanchez A., Miguelez Sanchez R., Pascual Allen D., Severe retinal phlebitis in ocular bartonellosis, Arch. Soc. Esp. Oftalmol. 78 (2003) 223-226.

[68] Dillon B., Valenzuela J., Don R., Blanckenberg D., Wigney D.I., Malik R., Morris A.J., Robson J.M., Iredell J., Limited diversity among human isolates of Bartonella henselae, J. Clin. Microbiol. 40 (2002) 4691-4699.

[69] Dolan M.J., Wong M.T., Regnery R.L., Jorgensen J.H., Garcia M., Peters J., Drehner D., Syndrome of Rochalimaea henselae adenitis suggesting cat scratch disease, Ann. Intern. Med. 118 (1993) 331-336.
[70] Drancourt M., Birtles R., Chaumentin G., Vandenesch F., Etienne J., Raoult D., New serotype of Bartonella henselae in endocarditis and cat-scratch disease, Lancet 347 (1996) 441-443.

[71] Drancourt M., Bodaghi B., Lepidi H., Le Hoang P., Raoult D., Intraocular detection of Bartonella henselae in a patient with HLA-B27 uveitis, J. Clin. Microbiol. 42 (2004) 1822-1825.

[72] Droz S., Chi B., Horn E., Steigerwalt A.G., Whitney A.M., Brenner D.J., Bartonella koehlerae sp. nov., isolated from cats, J. Clin. Microbiol. 37 (1999) 1117-1122.

[73] Ebani V.V., Cerri D., Andreani E., Cat scratch disease. Survey on the presence of Bartonella henselae among cats of Tuscany, New Microbiol. 25 (2002) 307-313.

[74] Eckart P., Tournade G., Amiour M., Guillot M., Courtheoux P., Rousselot P., Pseudotumoral presentation of cat scratch disease, Arch. Pediatr. 8 (2001) 393-396.

[75] Engbaek K., Lawson P.A., Identification of Bartonella species in rodents, shrews and cats in Denmark: detection of two $B$. henselae variants, one in cats and the other in the long-tailed field mouse, APMIS 112 (2004) 336-341.

[76] Engvall E.O., Brandstrom B., Fermer C., Blomqvist G., Englund L., Prevalence of Bartonella henselae in young, healthy cats in Sweden, Vet. Rec. 152 (2003) 366-369.

[77] Ellis B.A., Regnery R.L., Beati L., Bacellar F., Rood M., Glass G.G., Marston E., Ksiazek T.G., Jones D., Childs J.E., Rats of the genus Rattus are reservoir hosts for pathogenic Bartonella species: an Old World origin for a New World disease? J. Infect. Dis. 180 (1999) 220-224.

[78] Eskow E., Rao R.V., Mordechai E., Concurrent infection of the central nervous system by Bor relia burgdorferi and Bartonella henselae: evidence for a novel tick-borne disease complex, Arch. Neurol. 58 (2001) 1357-1363.

[79] Easley R.B., Cooperstock M.S., Tobias J.D., Catscratch disease causing status epilepticus in children, South Med. J. 92 (1999) 73-76.

[80] Escarmelle A., Delbrassine N., De Potter P., Cat scratch disease and Parinaud's oculoglandular syndrome, J. Fr. Ophtalmol. 27 (2004) 179-183.

[81] Fabbi M., De Giuli L., Tranquillo M., Bragoni R., Casiraghi M., Genchi C., Prevalence of Bartonella henselae in Italian stray cats: evaluation of serology to assess the risk of transmission of Bartonella to humans, J. Clin. Microbiol. 42 (2004) 264-268

[82] Fabbi M., Vicari N., Tranquillo M., Pozzi C., Prati P., De Meneghi D., Bertoletti I., Lauzi S., Guiso P., Genchi C., Prevalence of Bartonella henselae in stray and domestic cats in different Italian areas: evaluation of the potential risk of transmission of Bartonella to humans, Parassitologia 46 (2004) 127-129.

[83] Finkelstein J.L., Brown T.P., O'Reilly K.L., Wedincamp J. Jr., Foil L.D., Studies on the growth of Bartonella henselae in the cat flea (Siphonaptera: Pulicidae), J. Med. Entomol. 39 (2002) 915-919. 
[84] Foil L., Andress E., Freeland R.L., Roy A.F., Rutledge R., Triche P.C., O'Reilly K.L., Experimental infection of domestic cats with Bartonella henselae by inoculation of Ctenocephalides felis (Siphonaptera: Pulicidae) feces, J. Med. Entomol. 35 (1998) 625-628.

[85] Fournier P.E., Lelievre H., Eykyn S.J., Mainardi J.L., Marrie T.J., Bruneel F., Roure C., Nash J., Clave D., James E., Benoit-Lemercier C., Deforges L., Tissot-Dupont H., Raoult D., Epidemiologic and clinical characteristics of Bartonella quintana and Bartonella henselae endocarditis: a study of 48 patients, Medicine (Baltimore) 80 (2001) 245-251.

[86] Fournier P.E., Mainardi J.L., Raoult D., Value of microimmunofluorescence for diagnosis and follow-up of Bartonella endocarditis, Clin. Diagn. Lab. Immunol. 9 (2002) 795-801.

[87] Frean J., Arndt S., Spencer D., High rate of Bartonella henselae infection in HIV-positive outpatients in Johannesburg, South Africa, Trans. R. Soc. Trop. Med. Hyg. 96 (2002) 549-550.

[88] Gabler B., Linde H.J., Reischl U., Lohmann C.P., Disciform keratitis caused by Bartonella henselae infection: detection of a rare ocular complication of cat-scratch disease with PCR, Klin. Monatsbl. Augenheilkd. 217 (2000) 299302.

[89] Gerber J.E., Johnson J.E., Scott M.A., Madhusudhan K.T., Fatal meningitis and encephalitis due to Bartonella henselae bacteria, J. Forensic. Sci. 47 (2002) 640-644.

[90] Ghez D., Bernard L., Bayou E., Bani-Sadr F., Vallee C., Perronne C., Bartonella henselae infection mimicking a splenic lymphoma, Scand. J. Infect. Dis. 33 (2001) 935-936.

[91] Gillespie T.N., Washabau R.J., Goldschmidt M.H., Cullen J.M., Rogala A.R., Breitschwerdt E.B., Detection of Bartonella henselae and Bartonella clarridgeiae DNA in hepatic specimens from two dogs with hepatic disease, J. Am. Vet. Med. Assoc. 222 (2003) 47-51

[92] Glaus T., Hofmann-Lehmann R., Greene C., Glaus B., Wolfensberger C., Lutz H., Seroprevalence of Bartonella henselae infection and correlation with disease status in cats in Switzerland, J. Clin. Microbiol. 35 (1997) 2883-2885.

[93] Godet C., Roblot F., Le Moal G., Roblot P., Frat J.P., Becq-Giraudon B., Cat-scratch disease presenting as a breast mass, Scand. J. Infect. Dis. 36 (2004) 494-495.

[94] Gray A.V., Michels K.S., Lauer A.K., Samples J.R., Bartonella henselae infection associated with neuroretinitis, central retinal artery and vein occlusion, neovascular glaucoma, and severe vision loss, Am. J. Ophthalmol. 137 (2004) 187-189.

[95] Guptill L., Bartonellosis, Vet. Clin. North Am. Small Anim. Pract. 33 (2003) 809-825.

[96] Guptill L., Slater L., Wu C.C., Lin T.L., Glickman L.T., Welch D.F., HogenEsch H., Experimental infection of young specific pathogen-free cats with Bartonella henselae, J. Infect. Dis. 176 (1997) 206-216.
[97] Guptill L., Slater L.N., Wu C.C., Lin T.L., Glickman L.T., Welch D.F., Tobolski J., HogenEsch H., Evidence of reproductive failure and lack of perinatal transmission of Bartonella henselae in experimentally infected cats, Vet. Immunol. Immunopathol. 65 (1998) 177-189.

[98] Guptill L., Wu C.C., HogneEsch H., Slater L.N., Glickman N., Dunham A., Syme H., Glickman L., Prevalence, risk factors and genetic diversity of Bartonella henselae infections in pet cats in four regions of the United States, J. Clin. Microbiol. 42 (2004) 652-659.

[99] Gurfield A.N., Boulouis H.J., Chomel B.B., Heller R., Kasten R.W., Yamamoto K., Piemont Y., Coinfection with Bartonella clarridgeiae and Bartonella henselae and with different Bartonella henselae strains in domestic cats, J. Clin. Microbiol. 35 (1997) 2120-2123.

[100] Gurfield A.N., Boulouis H.J., Chomel B.B., Kasten R.W., Heller R., Bouillin C., Gandoin C., Thibault D., Chang C.C., Barrat F., Piemont Y., Epidemiology of Bartonella infection in domestic cats in France, Vet. Microbiol. 80 (2001) 185-198.

[101] Hadfield T.L., Warren R., Kass M., Brun E., Levy C., Endocarditis caused by Rochalimaed henselae, Hum. Pathol. 24 (1993) 1140-1141.

[102] Hadley S., Albrecht M.A., Tarsy D., Catscratch encephalopathy: a cause of status epilepticus and coma in a healthy young adult, Neurology 45 (1995) 196.

[103] Haimerl M., Tenter A.M., Simon K., Rommel M., Hilger J., Autenrieth I.B., Seroprevalence of Bartonella henselae in cats in Germany, J. Med. Microbiol. 48 (1999) 849-856.

[104] Hashkes P.J., Trabulsi A., Passo M.H., Systemic cat-scratch disease presenting as leukocytoclastic vasculitis, Pediatr. Infect. Dis. J. 15 (1996) 93-95.

[105] Hayem F., Chacar S., Hayem G., Bartonella henselae infection mimicking systemic onset juvenile chronic arthritis in a $21 / 2$-year-old girl, J. Rheumatol. 23 (1996) 1263-1265.

[106] Heller R., Artois M., Xemar V., De Briel D., Gehin H., Jaulhac B., Monteil H., Piemont Y., Prevalence of Bartonella henselae and Bartonella clarridgeiae in stray cats, J. Clin. Microbiol. 35 (1997) 1327-1331.

[107] Henn J.B., Liu C.H., Kasten R.W., VanHorn B.A., Beckett L.A., Kass P.H., Chomel B.B., Seroprevalence of antibodies against $\mathrm{Bar}$ tonella species and evaluation of risk factors and clinical signs associated with seropositivity in dogs, Am. J. Vet. Res. 66 (2005) in press.

[108] Hjelm E., McGill S., Blomqvist G., Prevalence of antibodies to Bartonella henselae, B. elizabethae and $B$. quintana in Swedish domestic cats, Scand. J. Infect. Dis. 34 (2002) 192-196.

[109] Hofmeister E.K., Kolbert C.P., Abdulkarim A.S., Magera J.M., Hopkins M.K., Uhl J.R., Ambyaye A., Telford S.R. 3rd, Cockerill F.R. 3rd, Persing D.H., Cosegregation of a novel Bartonella species with Borrelia burgdorferi and Babesia microti in Peromyscus leucopus, J. Infect. Dis. 177 (1998) 409-416. 
[110] Holmberg M., Mills J.N., McGill S., Benjamin G., Ellis B.A., Bartonella infection in sylvatic small mammals of central Sweden, Epidemiol. Infect. 130 (2003) 149-157.

[111] Honadel T.E., Chomel B.B., Yamamoto K. Chang C., Farver T.B., Seroepidemiology of Bartonella vinsonii subsp. berkhoffii exposure among healthy dogs, J. Am. Vet. Med. Assoc. 219 (2001) 480-484.

[112] Humar A., Salit I., Disseminated Bartonella infection with granulomatous hepatitis in a liver transplant recipient, Liver. Transpl. Surg. 5 (1999) 249-251.

[113] Jackson L.A., Perkins B.A., Wenger J.D., Cat scratch disease in the United States: An analysis of three national databases, Am. J. Public Health 83 (1993) 1707-1711.

[114] Jacobs R.F., Schutze G.E., Bartonella henselae as a cause of prolonged fever and fever of unknown origin in children, Clin. Infect. Dis. 26 (1998) 80-84.

[115] Jacomo V., Kelly P.J., Raoult D., Natural history of Bartonella infections (an exception to Koch's postulate), Clin. Diagn. Lab. Immunol. 9 (2002) 8-18.

[116] Jameson P., Green C., Regnery R., Dryden M., Marks A., Brown J., Cooper J., Glaus B., Greene R., Prevalence of Bartonella henselae antibodies in pet cats throughout regions of North America, J. Infect. Dis. 172 (1995) 1145-1149.

[117] Joseph A.K., Wood C.W., Robson J.M., Paul S.L., Morris A.J., Bartonella henselae bacteraemia in domestic cats from Auckland, N. Z. Vet. J. 45 (1997) 185-187.

[118] Juskevicius R., Vnencak-Jones C., Pathologic quiz case: a 17-year-old renal transplant patient with persistent fever, pancytopenia, and axillary lymphadenopathy. Bacillary angiomatosis of the lymph node in the renal transplant recipient, Arch. Pathol. Lab. Med. 128 (2004) e12-e14.

[119] Karras A., Thervet E., Legendre C., Groupe Cooperatif de transplantation d'Ile de France, Hemophagocytic syndrome in renal transplant recipients: report of 17 cases and review of literature, Transplantation 77 (2004) 238-243.

[120] Kelly P.J., Matthewman L.A., Hayter D., Downey S., Wray K., Bryson N.R., Raoult D., Bartonella (Rochalimaea) henselae in southern Africa - evidence for infections in domestic cats and implications for veterinarians, J. S. Afr. Vet. Assoc. 67 (1996) 182-187.

[121] Kelly P.J., Rooney J.J., Marston E.L., Jones D.C., Regnery R.L., Bartonella henselae isolated from cats in Zimbabwe, Lancet 351 (1998) 1706.

[122] Kempf V.A., Petzold H., Autenrieth I.B., Cat scratch disease due to Bartonella henselae infection mimicking parotid malignancy, Eur. J. Clin. Microbiol. Infect. Dis. 20 (2001) 732-733.

[123] Kerkhoff F.T., Bergmans A.M., van Der Zee A., Rothova A., Demonstration of Bartonella grahamii DNA in ocular fluids of a patient with neuroretinitis, J. Clin. Microbiol. 37 (1999) 4034-4038.
[124] Kitchell B.E., Fan T.M., Kordick D., Breitschwerdt E.B., Wollenberg G., Lichtensteiger C.A., Peliosis hepatis in a dog infected with Bartonella henselae, J. Am. Vet. Med. Assoc. 216 (2000) 519-523.

[125] Kobayashi K., Koga T., Oki T., Iwao K., Okumura A., Okinami S., Cat scratch disease with posterior segment involvement, Nippon Ganka Gakkai Zasshi 107 (2003) 99-104.

[126] Kodama T., Masuda H., Ohira A., Neuroretinitis associated with cat-scratch disease in Japanese patients, Acta Ophthalmol. Scand. 81 (2003) 653-657.

[127] Koehler J.E., Tappero J.W., Bacillary angiomatosis and bacillary peliosis in patients infected with human immunodeficiency virus, Clin. Infect. Dis. 17 (1993) 612-624.

[128] Koehler J.E., Glaser C.A., Tappero J.T., Rochalimaea henselae infection: A new zoonosis with the domestic cat as reservoir, JAMA 271 (1994) 531-535.

[129] Koehler J.E., Sanchez M.A., Garrido C.S., Whitfeld M.J., Chen F.M., Berger T.G., Rodriguez-Barradas M.C., LeBoit P.E., Tappero J.W., Molecular epidemiology of Bartonella infections in patients with bacillary angiomatosis-peliosis, N. Engl. J. Med. 337 (1997) 18761883.

[130] Koehler J.E., Sanchez M.A., Tye S., GarridoRowland C.S., Chen F.M., Maurer T., Cooper J.L., Olson J.G., Reingold A.L., Hadley W.K., Regnery R.R., Tappero J.W., Prevalence of Bartonella infection among human immunodeficiency virus-infected patients with fever, Clin. Infect. Dis. 37 (2003) 559-566.

[131] Kordick D.L., Breitschwerdt E.B., Relapsing bacteremia after blood transmission of Bartonella henselae to cats, Am. J. Vet. Res. 58 (1997) 492-497.

[132] Kordick D.L., Breitschwerdt E.B., Persistent infection of pets within a household with three Bartonella species, Emerg. Infect. Dis. 4 (1998) 325-328.

[133] Kordick D.L., Wilson K.H., Sexton D.J., Hadfield T.L., Berkhoff H.A., Breitschwerdt E.B., Prolonged Bartonella bacteremia in cats associated with cat-scratch disease patients, J. Clin. Microbiol. 33 (1995) 3245-3251.

[134] Kordick D.L., Swaminathan B., Greene C.E., Wilson K.H., Whitney A.M., O'Connor S., Hollis D.G., Matar G.M., Steigerwalt A.G., Malcolm G.B., Hayes P.S., Hadfield T.L., Breitschwerdt E.B., Brenner D.J., Bartonella vinsonii subsp. berkhoffii subsp. nov., isolated from dogs; Bartonella vinsonii subsp. vinsonii; and emended description of Bartonella vinsonii, Int. J. Syst. Bacteriol. 46 (1996) 704-709.

[135] Kordick D.L., Papich M.G., Breitschwerdt E.B., Efficacy of enrofloxacin or doxycycline for treatment of Bartonella henselae or Bartonella clarridgeiae infection in cats, Antimicrob. Agents Chemother. 41 (1997) 2448-2455.

[136] Kordick D.L., Hilyard E.J., Hadfield T.L., Wilson K.H., Steigerwalt A.G., Brenner D.J., 
Breitschwerdt E.B., Bartonella clarridgeiae, a newly recognized zoonotic pathogen causing inoculation papules, fever, and lymphadenopathy (cat scratch disease), J. Clin. Microbiol. 35 (1997) 1813-1818.

[137] Kordick D.L., Brown T.T., Shin K., Breitschwerdt E.B., Clinical and pathologic evaluation of chronic Bartonella henselae or Bartonella clarridgeiae infection in cats, J. Clin. Microbiol. 37 (1999) 1536-1547.

[138] Kordick S.K., Breitschwerdt E.B., Hegarty B.C., Southwick K.L., Colitz C.M., Hancock S.I., Bradley J.M., Rumbough R., Mcpherson J.T., MacCormack J.N., Coinfection with multiple tick-borne pathogens in a Walker Hound kennel in North Carolina, J. Clin. Microbiol. 37 (1999) 2631-2638.

[139] Kosoy M., Murray M., Gilmore R.D. Jr., Bai Y., Gage K.L., Bartonella strains from ground squirrels are identical to Bartonella washoensis isolated from a human patient, J. Clin. Microbiol. 41 (2003) 645-650.

[140] Krause R., Auner H.W., Daxbock F., Mulabecirovic A., Krejs G.J., Wenisch C., Reisinger E.C., Monoclonal and biclonal gammopathy in two patients infected with Bartonella henselae, Ann. Hematol. 82 (2003) 455-457.

[141] Lappin M.R., Kordick D.L., Breitschwerdt E.B., Bartonella spp. antibodies and DNA in aqueous humour of cats, J. Feline Med. Surg. 2 (2000) 61-68.

[142] La V.D., Clavel B., Leptez S., Aboudharam G., Raoult D., Drancourt M., Molecular detection of Bartonella henselae DNA in the dental pulp of 800-year-old French cats, Clin. Infect. Dis. 39 (2004) 1391-1394.

[143] La Scola B., Davoust B., Boni M., Raoult D. Lack of correlation between Bartonella DNA detection within fleas, serological results, and results of blood culture in a Bartonella-infected stray cat population, Clin. Microbiol. Infect. 8 (2002) 345-351.

[144] La Scola B., Liang Z., Zeaiter Z., Houpikian P., Grimont P.A., Raoult D., Genotypic characteristics of two serotypes of Bartonella henselae, J. Clin. Microbiol. 40 (2002) 2002-2008.

[145] La Scola B., Zeaiter Z., Khamis A., Raoult D. Gene-sequence-based criteria for species definition in bacteriology: the Bartonella paradigm, Trends Microbiol. 11 (2003) 318-321.

[146] Landau M., Kletter Y., Avidor B., Ephrat G., Ephros M., Brenner S., Giladi M., Unusual eruption as a presenting symptom of cat scratch disease, J. Am. Acad. Dermatol. 41 (1999) 833 836.

[147] Laycock G.M., Day M.J., Birtles R.J., Prevalence of Bartonella henselae in cats in the UK, Vet. Rec. 148 (2001) 219.

[148] Ledina D., Rincic J., Ivic I., Marasovic D., Ledina D., A child with Bartonella henselae osteomyelitis of the right humerus, Acta Dermatovenerol. Croat. 12 (2004) 92-95.

[149] Leighton F.A., Artsob H.A., Chu M.C., Olson J.G., A serological survey of rural dogs and cats on the southwestern Canadian prairie for zoonotic pathogens, Can. J. Public Health. 92 (2001) 67-71.

[150] Liston T.E., Koehler J.E., Granulomatous hepatitis and necrotizing splenitis due to Bartonella henselae in a patient with cancer: case report and review of hepatosplenic manifestations of Bartonella infection, Clin. Infect. Dis. 22 (1996) 951-957.

[151] Lozano F., Corzo J.E., Leon E.M., Rufo C., Loza A., Gomez-Mateos J.M., Massive hemoperitoneum: a new manifestation of bacillary peliosis in human immunodeficiency virus infection, Clin. Infect. Dis. 28 (1999) 911-912.

[152] Lucey D., Dolan M.J., Moss C.W., Garcia M., Hollis D.G., Wegner S., Morgan G., Almeida R., Leong D., Greisen K.S., Relapsing illness due to Rochalimaea henselae in immunocompetent hosts: implication for therapy and new epidemiological associations, Clin. Infect. Dis. 14 (1992) 683-688.

[153] Luria B.J., Levy J.K., Lappin M.R., Breitschwerdt E.B., Legendre A.M., Hernandez J.A., Gorman S.P., Lee I.T., Prevalence of infectious diseases in feral cats in Northern Florida, J. Feline Med. Surg. 6 (2004) 287-296.

[154] MacDonald K.A., Chomel B.B., Kittleson M.D., Kasten R.W., Thomas W.P., Pesavento P., A prospective study of canine infective endocarditis in northern California (19992001): emergence of Bartonella as a prevalent etiologic agent, J. Vet. Intern. Med. 18 (2004) 56-64.

[155] McGill S., Wesslen L., Hjelm E., Holmberg M., Rolf C., Friman G., Serological and epidemiological analysis of the prevalence of Bartonella spp. antibodies in Swedish elite orienteers 1992 1993, Scand. J. Infect. Dis. 33 (2001) 423-428.

[156] McGill S., Rajs J., Hjelm E., Lindquist O., Friman G., A study on forensic samples of Bartonella spp. antibodies in Swedish intravenous heroin addicts, APMIS 111 (2003) 507-513.

[157] Margileth A.M., Cat scratch disease, Adv. Pediatr. Infect. Dis. 8 (1993) 1-21.

[158] Margileth A.M., Recent advances in diagnosis and treatment of cat scratch disease, Curr. Infect. Dis. Rep. 2 (2000) 141-146.

[159] Margileth A.M., Baehren D.F., Chest-wall abscess due to cat-scratch disease (CSD) in an adult with antibodies to Bartonella clarridgeiae: case report and review of the thoracopulmonary manifestations of CSD, Clin. Infect. Dis. 27 (1998) 353-357.

[160] Markaki S., Sotiropoulou M., Papaspirou P., Lazaris D., Cat-scratch disease presenting as a solitary tumour in the breast: report of three cases, Eur. J. Obstet. Gynecol. Reprod. Biol. 106 (2003) 175-178.

[161] Marr B.P., Shields C.L., Shields J.A., Eagle R.C. Jr., Conjunctival cat-scratch disease simulating rhabdomyosarcoma, J. Pediatr. Ophthalmol. Strabismus 40 (2003) 302-303. 
[162] Marra C.M., Neurologic complications of Bartonella henselae infection, Curr. Opin. Neurol. 8 (1995) 164-169.

[163] Marston E.L., Finkel B., Regnery R.L., Winoto I.L., Graham R.R., Wignal S., Simanjuntak G., Olson J.G., Prevalence of Bartonella henselae and Bartonella clarridgeiae in an urban Indonesian cat population, Clin. Diagn. Lab. Immunol. 6 (1999) 41-44.

[164] Maruyama S., Nogami S., Inoue I., Namba S., Asanome K., Katsube Y., Isolation of Bartonella henselae from domestic cats in Japan, $\mathrm{J}$ Vet. Med. Sci. 58 (1996) 81-83.

[165] Maruyama S., Hiraga S., Yokoyama E., Naoi M., Tsuruoka Y., Ogura Y., Tamura K., Namba S., Kameyama Y., Nakamura S., Katsube Y. Seroprevalence of Bartonella henselae and Toxoplasma gondii infections among pet cats in Kanagawa and Saitama Prefectures, J. Vet. Med. Sci. 60 (1998) 997-1000.

[166] Maruyama S., Nakamura Y., Kabeya H., Tanaka S., Sakai T., Katsube Y., Prevalence of Bartonella henselae, Bartonella clarridgeiae and the 16S rRNA gene types of Bartonella henselae among pet cats in Japan, J. Vet. Med. Sci. 62 (2000) 273-279.

[167] Maruyama S., Sakai T., Morita Y., Tanaka S., Kabeya H., Boonmar S., Poapolathep A. Chalarmchaikit T., Chang C.C., Kasten R.W., Chomel B.B., Katsube Y., Prevalence of Bartonella species and 16s rRNA gene types of Bartonella henselae from domestic cats in Thailand, Am. J. Trop. Med. Hyg. 65 (2001) 783-787.

[168] Maruyama S., Kabeya H., Nakao R., Tanaka S., Sakai T., Xuan X., Katsube Y., Mikami T., Seroprevalence of Bartonella henselae, Toxoplasma gondii, FIV and FeLV infections in domestic cats in Japan, Microbiol. Immunol. 47 (2003) 147-153.

[169] Mason J.O. 3rd, Retinal and optic nerve neovascularization associated with cat scratch neuroretinitis, Retina 24 (2004) 176-178.

[170] Melter O., Hercik K., Weyant R.S., Janecek J., Nemec A., Mecera J., Gonzorova L., Branny P., Detection and characterization of feline $\mathrm{Bar}$ tonella henselae in the Czech Republic, Vet. Microbiol. 93 (2003) 261-273.

[171] Mexas A.M., Hancock S.I., Breitschwerdt E.B., Bartonella henselae and Bartonella elizabethae as potential canine pathogens, J. Clin. Microbiol. 40 (2002) 4670-4674.

[172] Millot F., Tailboux L., Paccalin M., Barret D., Zelinsky A., Thomas E., Levillain P., Guilhot F., Cat-scratch disease simulating a malignant process of the chest wall, Eur. J. Pediatr. 158 (1999) 403-405.

[173] Nasirudeen A.M., Thong M.L., Prevalence of Bartonella henselae immunoglobulin G antibodies in Singaporean cats, Pediatr. Infect. Dis. J. 18 (1999) 276-278.

[174] Ng S.O., Yates M.T., Ease of isolation and semiquantitative culture of Bartonella henselae from cats in Melbourne, Pathology 29 (1997) 333-334.

[175] Noah D.L., Bresee J.S., Gorensek M.J., Rooney J.A., Cresanta J.L., Regnery R.L., Wong J., del Toro J., Olson J.G., Childs J.E., Cluster of five children with acute encephalopathy associated with cat-scratch disease in south Florida, Pediatr. Infect. Dis. J. 14 (1995) 866-869.

[176] Nutter F.B., Dubey J.P., Levine J.F., Breitschwerdt E.B., Ford R.B., Stoskopf M.K., Seroprevalences of antibodies against Bartonella henselae and Toxoplasma gondii and fecal shedding of Cryptosporidium spp., Giardia spp., and Toxocara cati in feral and pet domestic cats, J. Am. Vet. Med. Assoc. 225 (2004) 1394-1398.

[177] O’Halloran H.S., Draud K., Minix M., Rivard A.K., Pearson P.A., Leber's neuroretinitis in a patient with serologic evidence of Bartonella elizabethae, Retina 18 (1998) 276-278.

[178] O'Reilly K.L., Bauer R.W., Freeland R.L., Foil L.D., Hughes K.J., Rohde K.R., Roy A.F., Stout R.W., Triche P.C., Acute clinical disease in cats following infection with a pathogenic strain of Bartonella henselae (LSU16), Infect. Immun. 67 (1999) 3066-3072.

[179] Ormerod L.D., Dailey J.P., Ocular manifestations of cat-scratch disease, Curr. Opin. Ophthalmol. 10 (1999) 209-216.

[180] Ormerod L.D., Skolnick K.A., Menosky M.M., Pavan P.R., Pon D.M., Retinal and choroidal manifestations of cat-scratch disease, Ophthalmology 105 (1998) 1024-1031.

[181] Pappalardo B.L., Correa M.T., York C.C., Peat C.Y., Breitschwerdt E.B., Epidemiologic evaluation of the risk factors associated with exposure and seroreactivity to Bartonella vinsonii in dogs, Am. J. Vet. Res. 58 (1997) 467-471.

[182] Pappalardo B.L., Brown T., Gookin J.L., Morrill C.L., Breitschwerdt E.B., Granulomatous disease associated with Bartonella infection in two dogs, J. Vet. Intern. Med. 14 (2000) 37-42.

[183] Peter J.B., Boyle M., Patnaik M., Hadfield T.L., Barka N.E., Schwartzman W.A., Penny R.S., Persistent generalized lymphadenopathy and non-Hodgkin's lymphoma in AIDS: association with Rochalimaea henselae infection, Clin Diagn. Lab. Immunol. 1 (1994) 115-116.

[184] Podsiadly E., Sokolowska E., TylewskaWierzbanowska S., Seroprevalence of Bartonella henselae and Bartonella quintana infections in Poland in 1998-2001, Ann. NY Acad. Sci. 990 (2003) 407-408.

[185] Podsiadly E., Chmielewski T., TylewskaWierzbanowska S., Bartonella henselae and Borrelia burgdorferi infections of the central nervous system, Ann. NY Acad. Sci. 990 (2003) 404-406.

[186] Pollock S.C., Kristinsson J., Cat-scratch disease manifesting as unifocal helioid choroiditis, Arch. Ophthalmol. 116 (1998) 1249-1251.

[187] Pretorius A.M., Kelly P.J., Birtles R.J., Raoult D., Isolation of Bartonella henselae from a serologically negative cat in Bloemfontein, 
South Africa, J. S. Afr. Vet. Assoc. 70 (1999) 154-155.

[188] Puligheddu M., Giagheddu A., Genugu F., Giagheddu M., Marrosu F., Epilepsia partialis continua in cat scratch disease, Seizure 13 (2004) 191-195.

[189] Raoult D., Fournier P.E., Drancourt M., Marrie T.J., Etienne J., Cosserat J., Cacoub P., Poinsignon Y., Leclercq P., Sefton A.M., Diagnosis of 22 new cases of Bartonella endocarditis, Ann. Intern. Med. 125 (1996) 646-652.

[190] Raoult D., Fournier P.E., VandeneschF., Mainardi J.L., Eykyn S.J., Nash J., James E., BenoitLemercier C., Marrie T.J., Outcome and treatment of Bartonella endocarditis, Arch. Intern. Med. 163 (2003) 226-230.

[191] Regnery R.L., Anderson B.E., Clarridge J.E. 3rd, Rodriguez-Barradas M.C., Jones D.C. Carr J.H., Characterization of a novel Rochalimaea species, $R$. henselae sp. nov., isolated from blood of a febrile, human immunodeficiency virus-positive patient, J. Clin. Microbiol. 30 (1992) 265-274.

[192] Regnery R., Martin M., Olson J., Naturally occurring "Rochalimaea henselae" infection in domestic cat, Lancet 340 (1992) 557-558.

[193] Regnery R.L., Childs J.E., Koehler J.E., Infections associated with Bartonella species in persons infected with human immunodeficiency virus, Clin. Infect. Dis. 21 (1995) S94-S98.

[194] Regnery R.L., Rooney J.A., Johnson A.M., Nesby S.L., Manzewitsch P., Beaver K., Olson J.G., Experimentally induced Bartonella henselae infections followed by challenge exposure and antimicrobial therapy in cats, Am. J. Vet. Res. 57 (1996) 1714-1719.

[195] Rocha J.L., Pellegrino L.N., Riella L.V., Martins L.T., Acute hemiplegia associated with cat-scratch disease, Braz. J. Infect. Dis. 8 (2004) 263-266.

[196] Rolain J.M., Fournier P.E., Raoult D., Bonerandi J.J., First isolation and detection by immunofluorescence assay of Bartonella koehlerae in erythrocytes from a French cat, J. Clin. Microbiol. 41 (2003) 4001-4002.

[197] Rolain J.M., Franc M., Davoust B., Raoult D. Molecular detection of Bartonella quintana, B. koehlerae, B. henselae, B. clarridgeiae, Rickettsia felis, and Wolbachia pipientis in cat fleas, France, Emerg. Infect. Dis. 9 (2003) 338-342.

[198] Rolain J.M., Brouqui P., Koehler J.E., Maguina C., Dolan M.J., Raoult D., Recommendations for treatment of human infections caused by Bartonella species, Antimicrob. Agents Chemother. 48 (2004) 1921-1933.

[199] Rolain J.M., Locatelli C., Chabanne L., Davoust B., Raoult D., Prevalence of Bartonella clarridgeiae and Bartonella henselae in domestic cats from France and detection of the organisms in erythrocytes by immunofluorescence, Clin. Diagn. Lab. Immunol. 11 (2004) 423-425.

[200] Roux V., Eykyn S.J., Wyllie S., Raoult D., Bartonella vinsonii subsp. berkhoffii as an agent of a febrile blood culture-negative endocarditis in a human, J. Clin. Microbiol. 38 (2000) 16981700.

[201] Roux V., Raoult D., Inter- and intraspecies identification of Bartonella (Rochalimaea) species, J. Clin. Microbiol. 33 (1995) 1573-1579.

[202] Sander A., Frank B., Paronychia caused by Bartonella henselae, Lancet 350 (1997) 1078.

[203] Sander A., Buhler C., Pelz K., von Cramm E., Bredt W., Detection and identification of two Bartonella henselae variants in domestic cats in Germany, J. Clin. Microbiol. 35 (1997) 584 587.

[204] Sander A., Posselt M., Oberle K., Bredt W., Seroprevalence of antibodies to Bartonella henselae in patients with cat scratch disease and in healthy controls: evaluation and comparison of two commercial serological tests, Clin Diagn. Lab. Immunol. 5 (1998) 486-490.

[205] Sander A., Zagrosek A., Bredt W., Schiltz E., Piemont Y., Lanz C., Dehio C., Characterization of Bartonella clarridgeiae flagellin (FlaA) and detection of antiflagellin antibodies in patients with lymphadenopathy, J. Clin. Microbiol. 38 (2000) 2943-2948.

[206] Schmoor P., Darie H., Maccari F., Gros P., Millet P., Cutaneous vasculitis disclosing cat-scratch disease, Ann. Dermatol. Venereol. 125 (1998) 894-896.

[207] Schulein R., Seubert A., Gille C., Lanz C., Hansmann Y., Piemont Y., Dehio C., Invasion and persistent intracellular colonization of erythrocytes. A unique parasitic strategy of the emerging pathogen Bartonella, J. Exp. Med. 193 (2001) 1077-1086.

[208] Serratrice J., Rolain J.M., Granel B., Ene N., Conrath J., Avierinos J.F., Disdier P., Raoult D., Weiller P.J., Bilateral retinal artery branch occlusions revealing Bartonella grahamii infection, Rev. Med. Interne 24 (2003) 629630.

[209] Signorini L., Simeone F., Tonegatti L., Colombini P., Cadeo B., Cristini F., Matteeli A., Viale P., Co-infection with Esptein-Barr virus and Bartonella henselae resulting in systemic bartonellosis, J. Infect. 45 (2002) 206-207.

[210] Smith H.M., Reporter R., Rood M.P., Linscott A.J., Mascola L.M., Hogrefe W., Purcell R.H., Prevalence study of antibody to rat-borne pathogens and other agents among patients using a free clinic in downtown Los Angeles, J. Infect. Dis. 186 (2002) 1673-1676.

[211] Smoller B.R., Madhusudhan K.T., Scott M.A., Horn T.D., Granuloma annulare - Another manifestation of Bartonella infection? Am. J. Dermatol. 23 (2001) 510-513.

[212] Solano-Gallego L., Bradley J., Hegarty B. Sigmon B., Breitschwerdt E., Bartonella henselae IgG antibodies are prevalent in dogs from southeastern USA, Vet. Res. 35 (2004) 585 595.

[213] Spach D.H., Koehler J.E., Bartonella-associated infections, Infect. Dis. Clin. North Am. 12 (1998) 137-155. 
[214] Spach D.H., Callis K.P., Paauw D.S., Houze Y.B., Schoenknecht F.D., Welch D.F., Rosen H., Brenner D.J., Endocarditis caused by Rochalimaea quintana in a patient infected with human immunodeficiency virus, J. Clin. Microbiol. 31 (1993) 692-694.

[215] Suksawat J., Xuejie Y., Hancock S.I., Hegarty B.C., Nilkumhang P., Breitschwerdt E.B., Serologic and molecular evidence of coinfection with multiple vector-borne pathogens in dogs from Thailand, J. Vet. Intern. Med. 15 (2001) 453-462.

[216] Tattevin P., Lellouche F., Bruneel F., Regnier B., De Broucker T., Bartonella henselae meningoencephalitis, Rev. Neurol. (Paris) 157 (2001) 698-700.

[217] Tsujino K., Tsukahara M., Tsuneoka H., Ichihara K., Furuya T., Kawauchi S., Oga A., Sasaki K., Clinical implication of prolonged fever in children with cat scratch disease, J. Infect. Chemother. 10 (2004) 227-233.

[218] Tsukahara M., Tsuneoka H., Iino H., Murano I., Takahashi H., Uchida M., Bartonella henselae infection as a cause of fever of unknown origin, J. Clin. Microbiol. 38 (2000) 1990-1991.

[219] Tsuneoka H., Umeda A., Tsukahara M., Sasaki K., Evaluation of indirect fluorescence antibody assay for detection of Bartonella clarridgeiae and seroprevalence of $B$. clarridgeiae among patients with suspected cat scratch disease, J. Clin. Microbiol. 42 (2004) 3346-3349.

[220] Tuttle A.D., Birkenheuer A.J., Juopperi T., Levy M.G., Breitschwerdt E.B., Concurren bartonellosis and babesiosis in a dog with persistent thrombocytopenia, J. Am. Vet. Med. Assoc. 223 (2003) 1306-1310, 1280-1281.

[221] Ueno H., Muramatsu Y., Chomel B.B., Hohdatsu T., Koyama H., Morita C., Seroepidemiological survey of Bartonella (Rochalimaea) henselae in domestic cats in Japan, Microbiol. Immunol. 39 (1995) 339-341.

[222] Ueno H., Hohdatsu T., Muramatsu Y., Koyama H., Morita C., Does coinfection of Bartonella henselae and FIV induce clinical disorders in cats? Microbiol. Immunol. 40 (1996) 617-620.

[223] Van Tooren R.M., Van Leusen R., Bosch F.H., Culture negative endocarditis combined with glomerulonephritis caused by Bartonella species in two immunocompetent adults, Neth. J. Med. 59 (2001) 218-224.

[224] Velho P.E., Cintra M.L., Uthida-Tanaka A.M., de Moraes A.M., Mariotto A., What do we (not) know about the human bartonelloses? Braz. J. Infect. Dis. 7 (2003) 1-6.

[225] Von Kobyletzki G., Nordmeier R., Stucker M., Sandmann M., Respondek M., Baier J., Altmeyer P., Acute generalized cat scratch disease in myelodysplastic syndrome, Hautarzt 52 (2001) 980-984.

[226] Wade N.K., Levi L., Jones M.R., Bhisitkul R., Fine L., Cunningham E.T. Jr., Optic disk edema associated with peripapillary serous retinal detachment: an early sign of systemic Bartonella henselae infection, Am. J. Ophthalmol. 130 (2000) 327-334.

[227] Walter R.S., Eppes S.C., Cat scratch disease presenting with peripheral facial nerve paralysis, Pediatrics 101 (1998) E13.

[228] Welch D.F., Carroll K.C., Hofmeister E.K., Persing D.H., Robison D.A., Steigerwalt A.G., Brenner D.J., Isolation of a new subspecies, Bartonella vinsonii subsp. arupensis, from a cattle rancher: identity with isolates found in conjunction with Borrelia burgdorferi and Babesia microti among naturally infected mice, J. Clin. Microbiol. 37 (1999) 2598-2601.

[229] Wesslen L., Ehrenborg C., Holmberg M., McGill S., Hjelm E., Lindquist O., Henriksen E., Rolf C., Larsson E., Friman G., Subacute Bartonella infection in Swedish orienteers succumbing to sudden unexpected cardiac death or having malignant arrhythmias, Scand. J. Infect. Dis. 33 (2001) 429-438.

[230] Wong M.T., Dolan M.J., Lattuada C.P. Jr., Regnery R.L., Garcia M.L., Mokulis E.C., LaBarre R.A., Ascher D.P., Delmar J.A., Kelly J.W. et al., Neuroretinitis, aseptic meningitis, and lymphadenitis associated with Bartonella (Rochalimaea) henselae infection in immunocompetent patients and patients infected with human immunodeficiency virus type 1, Clin. Infect. Dis. 21 (1995) 352-360.

[231] Wong T.Z., Kruskal J., Kane R.A., Trey G., Cat-scratch disease simulating lymphoma, J. Comput. Assist. Tomogr. 20 (1996) 165-166.

[232] Yamamoto K., Chomel B.B., Kasten R.W., Chang C.C., Tseggai T., Decker P.R., Mackowiak M., Floyd-Hawkins K.A., Pedersen N.C., Homologous protection but lack of heterologous-protection by various species and types of Bartonella in specific pathogen-free cats, Vet. Immunol. Immunopathol. 65 (1998) 191-204.

[233] Yamamoto K., Chomel B.B., Kasten R.W., Hew C.M., Weber D.K., Lee W.I., Koehler J.E., Pedersen N.C., Infection and re-infection of domestic cats with various Bartonella species or types: $B$. henselae type I is protective against heterologous challenge with $B$. henselae type II, Vet. Microbiol. 92 (2003) 73-86.

[234] Ying B., Kosoy M.Y., Maupin G.O., Tsuchiya K.R., Gage K.L., Genetic and ecologic characteristics of Bartonella communities in rodents in southern China, Am. J. Trop. Med. Hyg. 66 (2002) 622-627.

[235] Zangwill K.M., Hamilton D.H., Perkins B.A., Regnery R.L., Plikaytis B.D., Hadler J.L., Cartter M.L., Wenger J.D., Cat scratch disease in Connecticut. Epidemiology, risk factors, and evaluation of a new diagnostic test, N. Engl. J. Med. 329 (1993) 8-13.

[236] Zaror L., Ernst S., Navarrete M., Ballesteros A., Boroscheck D., Ferres M., Thibaut J., Serologic detection of Bartonella henselae in cats in the city of Valdivia, Chile, Arch. Med. Vet. 34 (2002) 103-110. 